Saint Louis University School of Law

Scholarship Commons

All Faculty Scholarship

2015

Property and Political Community: Democracy, Oligarchy, and the Case of Ukraine

Monica E. Eppinger

Saint Louis University School of Law

Follow this and additional works at: https://scholarship.law.slu.edu/faculty

Part of the Comparative and Foreign Law Commons, European Law Commons, and the International Law Commons

Recommended Citation

Eppinger, Monica E., Property and Political Community: Democracy, Oligarchy, and the Case of Ukraine (November 17, 2014). 47 George Washington International Law Review 825 (2015).

This Article is brought to you for free and open access by Scholarship Commons. It has been accepted for inclusion in All Faculty Scholarship by an authorized administrator of Scholarship Commons. For more information, please contact erika.cohn@slu.edu, ingah.daviscrawford@slu.edu. 


\title{
PROPERTY AND POLITICAL COMMUNITY: DEMOCRACY, OLIGARCHY, AND THE CASE OF UKRAINE
}

\author{
MONICA EPPINGER*
}

\begin{abstract}
Widening wealth gaps in Western democracies have brought new scrutiny to relationships between property and political community. For the prior quarter century, Western legal scholars have urged privatization around the globe as the key to a virtuous circle of "market democracy." This Article traces the origins of the market democracy consensus to ideas that identify positive features of political community-liberty, wealth, or democracy - with private property ownership. Fieldwork in Ukraine, where Western privatization advice was followed at a time of founding a new polity, provides data to compare predictions with outcomes. Two unexpected figures - the Oligarch and the Precariat-emerge from the newly privatized countryside. Research into the micropractices of privatization counter-intuitively exposes private property as potentially working against democracy. The findings from this research are that oligarchy is a possibility, distribution is a problem, and relationships between property and democracy are not always mutually felicitous.
\end{abstract}

\section{Introduction: Property and Political Community}

The relationship between property and political community has recently come under renewed scrutiny. Anxiety about the resilience of democracy in a time of widening wealth gaps ${ }^{1}$ and growing

* Assistant Professor of Law and of Anthropology, Saint Louis University. J.D., Yale Law School and Ph.D., University of California Berkeley. I thank Susan Rose-Ackerman, Bob Ellickson, Jim Whitman, Carol Rose, Intisar Rabb, and Duncan Kennedy for feedback and Laura Nader for support for the project. Portions of this paper benefitted from presentation at the Stanford/Yale Junior Faculty Workshop, an American Society for Comparative Law workshop, the Danyliw Seminar in Contemporary Ukrainian Studies, the American Association of Law Schools Comparative Law session, at Harvard, New York University, Wake Forest, Washington University, and Saint Louis University Schools of Law, and at Kyiv Polytechnic Institute Department of Sociology. Research was supported by National Science Foundation, Fulbright-Hays, and Yale Law School Olin fellowships; and Yale Agrarian Studies, Yale European Studies, and University of California Berkeley Program in Post-Soviet Studies grants.

1. See John P. McCormick, Keep the Public Rich, but the Citizens Poor: Economic and Political Inequality in Constitutions, Ancient and Modern, 34 CARdozo L. Rev. 879 (2013) (arguing economic inequality invariably undermines political equality and hence liberty); see also Joseph E. Stiglitz, The Price of Inequality: How Today's Divided Society Endangers 
institutional closeness between governments and financial capital ${ }^{2}$ have raised concerns in industrialized democracies of a drift towards oligarchy. ${ }^{3}$ While questions about property and political community go back at least to Aristotle, ${ }^{4}$ the post-Cold War period has seen the role of property in democracy celebrated as much as investigated. ${ }^{5}$ New developments suggest the recent past deserves reconsideration.

The dearth of critical examination is all the more surprising given property's prominence. Property in theory and property in ideology are two protagonists of the history of the twentieth century. Major social theories like socialism and liberalism depend on property as their primary explanatory principle. Theory inspired twentieth-century revolutions that took fundamental change in land tenure regime as a central goal. Property assumed an equally prominent role in ideology during a Cold War in which geopolitical rivals made differing property regimes a linchpin of self-definition. At the Cold War's end in 1991, property theory became a tool for diagnosing systemic ills and property doctrine, a proposed remedy. It was a time when, surveying draft post-socialist constitu-

Our Future (2013); Timothy Noah, The Great Divergence: America's Growing IneQuality Crisis and What We Can Do About It (2013).

2. See, e.g., Simon Johnson, Financial Oligarchy and the Crisis, 16 Brown J. World AfF. $159,159-60$ (2010) (arguing the 2008 financial crisis resulted from "political capture," the financial sector's relationships with government); see also, e.g., Simon Johnson, The Quiet Coup, Atlantic (May 2009), http://www.theatlantic.com/magazine/archive/2009/05/ the-quiet-coup/307364/ (explaining prevalence of "cultural capture," a form of oligarchy ruling not through coercion but through suasion in favor of more and unregulated finance).

3. See Joseph Fishkin \& William E. Forbath, The Anti-Oligarchy Constitution, 94 B.U. L. REv. 669, 669-70 (2014) (proposing that as structures of opportunity narrow, the U.S. is becoming an oligarchy rather than a republic).

4. See Aristotle, Politics 191-92 (Benjamin Jowett trans., Random House 1943 (306 B.C.)) ("Great then is the good fortune of a state in which the citizens have a moderate and sufficient property; for where some possess much, and the others nothing, there may arise an extreme democracy, or a pure oligarchy; or a tyranny may grow out of either extreme"); see also, e.g., 1 Montesquieu, 1 Spirit of The Laws, 50-51 (facsimile reprod. 1984) (1751) (suggesting republican virtue cannot bear great disparities of wealth, requiring equality and "mediocrity" of fortunes), cited in Carol Rose, Property as the Keystone Right?, 71 Notre Dame L. Rev. 329, 359 (1996) [hereinafter Rose, Keystone Right].

5. See, e.g., John Williamson, What Washington Means by Policy Reform, in Latin American Adjustment: How Much Has Happened? 5 (John Williamson ed., 1990) (identifying ten principles followed by Latin American governments to deal with the 1980s debt crises, including privatization of state enterprises and legal security for property rights, a set that became known as "the Washington Consensus"). 
tions, the right to real property could be called the "most sacred." 6 It was, in legal scholarship, the Property Moment. ${ }^{7}$

A goal emerged for Western-led reform efforts around the world, ${ }^{8}$ a system of economics and governance that came to be called "market democracy." 9 This seemingly straightforward goal-still guiding action today-unites under one banner several competing (and in some respects, unreconciled) programs. ${ }^{10}$ Analyzing its origins and outcomes is a primary goal of this Article. As a policy and ideal, "market democracy" was articulated and propagated from West to East across many powerful discourses: economics, technical advising, diplomacy, advertising. This Article focuses on law as a discipline from which some of the logic of market democracy emerged and as the discipline upon which other disciplines relied to test the sufficiency of logical claims. This Article

6. Mark Ellis, Drafting Constitutions: Property Rights in Central and Eastern Europe, 19 YALE J. INT'L L. 197, 198 (1994) (calling the right to real property "the most sacred" among economic and social rights in draft post-Socialist constitutions).

7. As evidence of interest in property as a constitutional right in U.S. legal scholarship of the time, see, e.g., James W. Ely, JR., The Guardian of Every Other Right: A Constitutional History of Property Rights (1992). Coincidentally, the sunset of the socialist bloc coincided with a growing "property rights movement" in the United States. On the latter, see Rose, Keystone Right, supra note 4, at 329 n.2 (1996) (finding property rights movement expressed in state legislatures' acts to restrain governmental "takings" of private property). As an example of scholarly advocacy in the Property Rights movement, see, e.g., Brief for The Cato Institute as Amicus Curiae Supporting Petitioners, Kelo et al. v. City of New London, 545 U.S. 469 (2005) (No. 04-108) (authored by Richard Epstein and Mark Moller).

8. For critique of U.S.-led economic reform efforts in central and eastern Europe, see Janine R. Wedel, Collision and Collusion: The Strange Case of Western Aid to Eastern Europe (2011) [hereinafter Wedel, Collision and Collusion]. For analysis of pattern of Western attempts to transplant legal systems and norms, see UGO MATTEI AND Laura Nader, Plunder: When the Rule of Law is Illegal (2008). But see James Q. Whitman, Western Legal Imperialism: Thinking about Deep Historical Roots, 10 Theoretical InQ. L. 305 (2009) (arguing the roots of Western attempts to export legal reform are part of a missionizing impulse extending much farther back than Mattei and Nader posit, to 7001000 C.E.).

9. See, e.g., Anthony Lake, U.S. Nat'l Sec. Adviser, From Containment to Enlargement, Remarks at Johns Hopkins University School of Advanced International Studies (Sept. 21, 1993), [hereinafter Lake, Containment to Enlargement], available at http:// www.mtholyoke.edu/acad/iterl/lakedoc.html (stating the U.S. in 1993 has an obligation and opportunity to lead "people on every continent" who are concluding "America's core concepts - democracy and market economics" are "the most productive and liberating ways to organize their lives."). See infra Section II.C. (discussing the emergence of a "market democracy" consensus from discordant property traditions).

10. See Gregory S. Alexander, A Fourth Way?: Economic Transformation in the Post-Communist World, 20 Cornell L. F. 3, 8 (1993) [hereinafter Alexander, A Fourth Way] (warning that "market economy" is a vague concept that permits people to read into it a range of conflicting values). 
also focuses on law because Western legal academics inserted themselves into advocacy of post-Soviet reforms in powerful ways.

Western thinkers, predicting felicitous relationships between private property and democracy, ${ }^{11}$ identified private property as the key to market democracy. ${ }^{12}$ Legal scholars weighed in. ${ }^{13}$ At a time of fundamental systemic change, a basic political and economic reordering, Property was set loose to do its work. Property became the sine qua non of peaceful regime change, a fundamental constitutional issue, the key right to a liberal order. ${ }^{14}$

We now enjoy a vantage from which to assess results in years following the Property Moment. Did property deliver? Or rather, What did property deliver? This Article, following Frank Michelman and Duncan Kennedy's admonition that the economic efficiency of private property be tested rather than assumed ${ }^{15}$, likewise subjects the promises of Property in regard to political community to empirical investigation. The case I investigate is postSoviet transformation in Ukraine.

Ukraine presents a prime candidate for such a study for several reasons. An object of intense Western advising, ${ }^{16}$ Ukraine adopted

11. See Lake, Containment to Enlargement, supra note 9 ("Both processes strengthen each other: democracy alone can produce justice, but not the material goods necessary for individuals to thrive; markets alone can expand wealth, but not that sense of justice without which civilized societies perish.").

12. See infra Section II.C. (tracing the place of private property in discussions of democracy reforms). But see Stephen S. Cohen \& Andrew Schwartz, The Tunnel at the End of the Light: Privatization in Eastern Europe, 7 Transnat'L Law. 7, 11-12 (1994) [hereinafter Cohen \& Schwartz, Privatization in Eastern Europe] (arguing against rapid privatization in former socialist countries to allow time for development of regulatory institutions).

13. See, e.g., Rose, Keystone Right, supra note 4; Cass R. Sunstein, On Property and Constitutionalism, 14 Cardozo L. Rev. 907 (1993); Alexander, A Fourth Way, supra note 10. At the time, Michael Heller did not participate as an academic; rather, he advised directly, serving as a World Bank consultant to post-socialist governments on matters including land privatization; see Michael A. Heller, Property Rights: A View from the Trenches, 19 Yale J. Int'L L. 203, 203 [hereinafter Heller, View from the Trenches]. For his scholarly reflection on the changes of that time, see Michael A. Heller, The Tragedy of the Anti-Commons: Property in the Transition from Marx to Markets, 111 Harv. L. Rev. 621, 628 (1998) [hereinafter Heller, AntiCommons].

14. See Rose, Keystone Right, supra note 4 (summarizing seven arguments that property is the key to liberal order).

15. Duncan Kennedy \& Frank Michelman, Are Property and Contract Efficient?, 8 HoFSTRA L. REv. 711, 744, 749 (1980) (arguing that the incentive effects of property and contract rules cannot be known without empirical investigation).

16. Ukraine became recipient of the third-largest package of U.S. assistance in the world, second only to assistance provided to Israel and Egypt under the Camp David Accords; subtracting military assistance, Ukraine was first in U.S. assistance in the world by 1996. See 1996: The Year in Review, Ukr. WeEkLY (Dec. 29, 1996), http://www.ukr weekly.com/old/archive/1996/529609.shtml; see also OfFice of THE COORDinATOR OF U.S. Assistance to the NIS, U.S. Dep't St., Gov't Assistance to and Cooperative Activities 
property reform as part of a fundamental political restructuring. This investigation is timely, coming after privatization has passed through its legislated implementation period. Finally, Ukraine is currently in an acute position of taking stock and assessing the results of post-Soviet experiments. In a time of our own concerns about property and political community, we face a common set of questions.

Taking Western advice, the Ukrainian parliament passed a Land Code providing rights to private ownership in land in 2001 with a five-year implementation period beginning in 2002. ${ }^{17}$ To investigate the results, I conducted on-site field research on the Land Code and its implementation at intervals beginning shortly after the implementation period began in 2002, totaling more than twenty months over twelve years. ${ }^{18}$ Among agriculturalists, I conducted interviews and observation on two different types of farms: parcels farmed by smallholders as allocated by the state and farmlands that have since been consolidated. ${ }^{19} \mathrm{I}$ also interviewed parliamentarians, rural outmigrants, judges, small agribusiness managers, and oligarchs. This Article reports my findings.

Assessing gains or losses from following Western property doctrine is worthwhile in itself, but market democracy advising promised more. Accordingly, this Article concentrates on critical inquiry into claims about relationships between property and political community. Amid a fresh preoccupation with the "basic conception of political community" 20 and analysis of structural features

with the New Indep. States of the Former Soviet Union FY 1996 Report (1997), available at http://www.fpa.org/usr_doc/37315.pdf.

17. Land Code of Ukraine, 2001 Laws No. 2905-III (Uryadovy Kur'yer [Government Courier, the official reporter of the Cabinet of Ministers of Ukraine], Nov. 15, 2001) [hereinafter Land Code].

18. Field research in Ukraine took place over two months in 2002, fourteen months in 2006-2007, and in follow-up trips in 2009, 2012, 2013, and 2014.

19. This research was further informed by my two and half years' experience as a U.S. diplomat stationed in Embassy Kiev, serving as embassy liaison to parliament during the drafting, passage, and early implementation of Ukraine's post-Soviet constitution in 1996 and 1997. See Bureau of Democracy, Hum. Rts. and Lab., U.S. Dep't St., Country Human Rights Report on Ukraine (1996), available at http://www.state.gov/www/global/ human_rights/1996_hrp_report/ukraine.html.

20. "Political community" emerged in U.S. Constitutional jurisprudence in the early 1970s. See Dunn v. Blumstein, 405 U.S. 300, 344 (1971) (allowing a state law imposing residence requirement for voting rights because it may be necessary "to preserve the basic conception of a political community"), aff'd in Sugarman v. Dougall, 413 U.S. 634, 642-43 (1971) (recognizing a state's broad power to define its "political community"). 
that shape it, ${ }^{21}$ relationships between property and political community deserve their analytical due.

\section{ROADMAP}

The first two Sections of this Article describe encounters between U.S. bodies of property theory and Soviet practice in order to trace the emergence of market democracy as an ideal with property at its core. In Section I, I identify three significant bodies of thought - three explanations of the relationship between property and political community-shaping Western legal thinkers' background $^{22}$ in the 1980 s and 1990s. These bodies of thought have their own folk histories, totemic personages, and consciously deployed icons. My aim here is not historiographical, to relate for each a definitive version or to "correct" misperceptions of current thinkers about their own intellectual roots. The historical material cited is, instead, meant to relate these thinkers' accounts on their own terms. ${ }^{23}$ Ideas matter, as do their embedded understandings of human nature. Reviewing their various claims and logics helps us to understand what is meant by "market democracy" and how that term encompasses goals arising out of uncoordinated and potentially irreconcilable idioms.

U.S. legal thinkers informed by these three accounts of property encountered a well-developed body of property theory, legal doctrine, and practice in the former Soviet republics. In Section II, I briefly describe Soviet property in theory and practice, the institutional field upon which Western legal theories were brought to bear. The second part of Section II deals with encounters between U.S. theory and Soviet experience. A critique of the Soviet property regime, extending Western scholarship on the commons, became formulated as diagnosis and contributed to casting private property as remedy. The process of getting from socialism to market democracy, the "curative process," was privatization. Together,

21. See James A. Gardner, Federalism E Subnational Political Community, 127 Harv. L. Rev. F. 153, 154-55 (2013-2014) (describing qualities that make a community a "political community," as a state should be, if it is to check overextensions of national power under U.S. constitutional plan); see also Gregory S. Alexander \& Eduardo M. Peñalver, Properties of Community, 10 Theoretical Inquiries L. 127 (2009) [hereinafter Alexander \& Peñalver, Properties of Community].

22. For explanation of background, see John Searle, Intentionality: An Essay in the Philosophy of Mind 143-44 (1983).

23. The method of trying to understand a person's patterns of thought on their own terms undertaken here is referred to as an emic approach. (The alternative is a cross-cultural etic approach.) See Kenneth Pike, Language in Relation to a Unified Theory of the Structure of Human Behavior (1954). 
the first two Sections describe the work that property as an analytic category does in competing theories of the late twentieth century. Overall, they give background for Sections III and IV, which show how the patient fared once the remedy was applied.

Section III, reporting from the field, tells the story of a postprivatization rural boomtown characterized by explosive growthnot in population, but in the productivity of its agricultural sector. It shows how privatization operates together with other experimental forms in the lived experience of post-socialism, how oligarchy puts down roots in the soil of private property ownership. Section IV describes alternative spaces away from the intense cultivation of property profits and patron-client relations, in which implementation of the same laws has given rise to different outcomes. What I call the "ghost town" is deserted both of prosperity and part of its population, but not of democratic forms, which are robust and lively. The central figure arising from each of these contexts defies predictions. These two Sections reveal some of the micropractices of transition to a private property regime and the legal doctrines that provide the framework for those practices. This is the context in which a nascent oligarchy has been built and from which impoverished former collective farmers have fled. The former became the object of mass protests in Ukraine in 2014; the latter, members of the masses that toppled the government. ${ }^{24}$ Between the two, we find practices, patterns of thought, and forms of sociability that may be assets in constructing a livable future.

Existing scholarship and policy present the relationship between private property ownership and democratic governance as a virtuous circle: property, serving both economic and political ends, promotes both prosperity and democracy. ${ }^{25}$ My main finding reported in the Conclusion is that the beneficial effects of private property ownership on democracy are not as uniform as predicted. When it comes to wealth gaps, political community, and state vulnerability, Ukraine may present a precocious case to which those in other industrialized countries should attend. This is a moment of great vulnerability for the Ukrainian state, and the story narrated here gives background on key features of the political structures that have made it so. In addition to rounding out the picture of what is occurring on the ground in Ukraine, we gain insight into settings

24. See, e.g.. Andrew Higgins, With President's Departure, Ukraine Moves Toward a Murky Future, N.Y. TIMEs, Feb. 23, 2014, at A15 (describing mass demonstrations and the flight of the government they opposed).

25. See infra Part II.C. 
closer to home through a fresh perspective on relationships between property and political community. This work may provide a humbling reminder of unintended consequences of exporting legal doctrines, or inspire wider consideration of the illiberal results of liberal initiatives.

\section{Property and Political Community: Three Accounts}

With the passing of Soviet state socialism, a new system of political and economic organization including a new property regime could be considered in its place, evoking for Western scholars and experts pre-existing understandings of how property works in constituting political community. The bodies of theory outlined in this Section each provide an account of how property and systems of governance are related. In each, a different figure ${ }^{26}$ of the property owner emerges. Discerning that figure lends insight into assumptions made about human nature embedded in the theory. In other words, just as each property theory has its own account of the relationship between property and polity, its own political theory and sociology, each property theory also incorporates its own understanding of the human, its own anthropology. Given the focus on political community, this Section concentrates on political rather than economic claims of property theory. What follows here are paradigmatic accounts, reflecting a moment in which nuance was flattened; these accounts may seem commonplace, but it is in their very taken-for-grantedness that their power lays. ${ }^{27}$ It is also there that we find their capacity to surprise us. ${ }^{28}$ Together they provide some of the intellectual equipment that U.S. legal thinkers brought to bear when the Soviet Union broke up in 1991.

\section{A. The Liberty of Persons Account}

The Liberty of Persons account starts from a conceptual division between a private sphere and a state sphere. The private is a trusted sphere for activity, interaction, and association between individual actors. The state and the exercise of its authority are

26. These figures are not, strictly speaking, members of an economic "class." They stand for those positioned in a particular way within the economic order and sharing certain formations of affect, ethics, and aesthetics. They are characterized by their hopes, dreams, and fears as much as by economic activities or social affiliation.

27. For an anthropological account of the power of things taken for granted, see generally Laura Nader, Controlling Processes: Tracing the Dynamic Components of Power, 38 CurRENT ANTHRopology 711 (1997).

28. See infra Sections III \& IV (relating some of the actual outcomes instituting private property). 
viewed skeptically. Personal autonomy and individual liberty are most prized, ${ }^{29}$ and for them, property plays a major role in two respects. I refer to them as "liberty against the state" and "liberty within the private."

\section{Property Liberty: Against the State}

In the first version of the Liberty of Persons account, property rights are an element of personal autonomy, or even a necessary condition of individual liberty. ${ }^{30}$ The private sphere provides the individual a space for defense against the depredations of the state. State and private are co-constitutive in this account. By that, I mean the shape of one determines the shape of the other. To understand the private sphere in which property plays such an important role in the Liberty of Persons account, one must understand how its adherents conceptualize the nature of the state and the threats the state poses against which the private sphere is to provide defense.

The contemporary Liberty of Persons account still bears outlines of the shape it took in the eighteenth century, when absolutist aspirations had arisen across Europe and revolution against them was fomenting in the Americas. ${ }^{31}$ The writings of Englishmen John Trenchard and Thomas Gordon from that time, collectively called Cato's Letters ${ }^{32}$, are emblematic of a Libertarian philosophical

29. See, e.g., Steve Pejovich, Liberty, Property Rights, and Innovation in Eastern Europe, 9 CAto J. 57, 57-58 (1989) (While the "real issue" in comparing socialism and capitalism is their "comparative efficiency," the value of a social system is simply "not verifiable by econometric techniques" because it must be evaluated regarding its effects on "liberty, human creativity, and new opportunities.").

30. See, e.g., Richard Epstein, Takings: Private Property and the Power of Eminent Domain (1985) [hereinafter Epstein, TAKings].

31. By "absolutism," detractors in England and on the continent meant mechanisms and procedures by which the arbitrary power of the state - principally, but now exclusively the monarch - was enhanced. Strictly speaking, absolutist monarchy was only achieved in Denmark when the estates dissolved themselves and transferred all political power to the king, but monarchists elsewhere aspiring to it took measures to weaken or evade the powers of representative bodies. For discussion of absolutism in the context of a history of ideas, see generally, Quentin Skinner, The Foundations of Modern Political Thought: Vol. II: The Age of Reformation (1978).

32. Writing under the pseudonym "Cato," Trenchard and Gordon produced a series of articles (144 in three years, published in the London Journal and British Journal) that became known collectively as Cato's Letters. On the circulation of Cato's Letters and currency of their ideas among American revolutionaries, see, e.g., Clinton Rossiter, Seedtime of the Republic: the Origin of the American Tradition of Political Liberty 141 (1953) (asserting Cato's Letters rather than Locke's Civil Government was the most popular source of political ideas in colonial America). 
stance still trenchant today. ${ }^{33}$ Cato's Letter No. 25 gives a representative example of influential early Libertarian views on state power, tyranny, and property. ${ }^{34}$ Tyranny, in this account, stems from structural sources for which any particular form of government, including representative government, is no panacea. Any government falls prey to a divergence in interests between those in power and those governed. ${ }^{35}$ Access to state power and the nature of dominion, rather than any particular person's failings, leads inevitably to tyrannical tendencies in rulers. ${ }^{36}$

Power is, in the Cato account, uniquely, an attribute of the state. In its less suspicious iterations, power is amoral, like fire; like fire, power has the potential to serve humanity but is inherently dangerous and must be controlled. ${ }^{37}$ Unrestrained, or "lawless" power" breeds many ills, visiting on individuals bloodshed and infringement of property rights ${ }^{39}$ and on nations, aggregate biopolitical and wealth effects. ${ }^{40}$ Where "lawless power" is the problem, law can be one of the solutions ${ }^{41}$ (a nascent argument for a rule of law): legal restraints should first be used to control those in power. ${ }^{42}$ The state should also safeguard the private sphere by protecting property rights and preserving law and order, ${ }^{43}$ in a world

33. See, e.g., About Cato, Cato Inst., http://www.cato.org/about (last visited Mar. 18, 2015) (explaining that U.S. Libertarian think-tank The Cato Institute takes its name from the collective name for the Trenchard-Gordon articles, Cato's Letters).

34. Thomas Gordon, Cato's Letter No. 25, Considerations on the Destructive Spirit of Arbitrary Power. With the Blessings of Liberty, and our own Constitution, (Apr. 15, 1721), available at http://classicliberal.tripod.com/cato/letter025.html.

35. Id. (Divergence in interests between governing and governed is "the hard fate of the world.").

36. Id. (A "cruel spirit" may not be a tyrant's natural character but is owing to "the nature of the dominion" he exercises.).

37. $I d$.

38. Id. ("Lawless power" is so "monstrous" and the human so weak that a person "ought never to be trusted with a power that is boundless.").

39. Id. (An arbitrary prince and his subjects destroy one another, they plotting against his life, he "shedding their blood, and plundering them of their property.").

40. Id. "The great continent of America is almost unpeopled, the Spaniards having destroyed, 'tis thought, about forty millions of its natives . . ."). See also, e.g., Mitton Friedman, The Relation between Economic Freedom and Political Freedom, CapitalISM AND FREEDOM 7-21 (1962).

41. Id. ("Good laws make a good prince, if he has a good understanding; but the best men grow mischievous when they are set above laws [...]").

42. Id. (Because power "is apt to break its bounds, in all good governments nothing, or as little as may be, ought to be left to chance, or the humours of men in authority: All should proceed by fixed and stated rules, and upon any emergency, new rules should be made.").

43. James Madison, Property (Mar. 27, 1792), reprinted in 14 The Papers of James Madison 266, 266-68 (Robert Rutland et al. eds., 1983) ("Government is instituted to protect property of every sort ....."); see also Friedman, "The Role of Government in a Free 
in which the primary threat to property owners comes from the state itself.

In this account, property proves an inseparable part of the conception of the private sphere. Private property in this schema becomes a setting, a redoubt, for the autonomous person, ${ }^{44}$ so important for the individual that rights to private property have been characterized as central to a system of "natural rights" 45 inhering to any physical person. There are differences across iterations but in any of the anti-tyranny Liberty of Persons accounts, private property is indispensable either as a constituent element of the private sphere, as a right conceptually inseparable from individual liberty, or as a precondition for individual liberty. The proper role (if any) for government is reduced to restraining rulers and safeguarding the private sphere; for many, that becomes synonymous with safeguarding property rights. Protecting property from government seizure is an important part of guarding against tyranny. ${ }^{46}$

\section{Property Liberty: Within the Private}

There is a second respect in which property figures in the Liberty of Persons account, less concerned with the state than with what happens within that private sphere itself. Property is a place where ordinary people generate rules to order mutual expectations or settle disputes, without making recourse to formal law or state

Society," Capitalism and Freedom, supra note 40, at 22-36; Douglas W. Kmiec, The Coherence of the Natural Law of Property, 26 VAL. U. L. REv. 367, 383 (1991) (arguing that preventing harms to property is a governmental function consistent with the natural rights tradition).

44. See Robert Ellickson, The Household: Informal Order Around the Hearth 1 (2008) [hereinafter Ellickson, Housenold] (characterizing property in the private sphere as an individual's retreat from social life).

45. "The system of natural rights usually refers to the rights to acquire and own property, and to have exclusive liberty to control one's own person and labor." Richard Epstein, A Last Word on Eminent Domain, 41 U. Miami L. Rev. 253, 257 (1986).

46. This scholarship claims as its heritage, inter alia, James Madison's drafting of the Takings Clause. See U.S. Const. amend. V (Takings Clause); Creating the Bill of Rights: The Documentary Record From the First Federal Congress xiii-xiv, 11-15 (Helen E. Veit et al. eds., 1991) (reproducing Madison's proposed resolution of amendments that became the Bill of Rights, including the Takings clause); William Michael Treanor, The Original Understanding of the Takings Clause and the Political Process, 95 Colum. L. Rev. 782, 791, 837 (1995) (analyzing Madison's role in drafting of Takings Clause), cited in John F. Hart, "A Less Proportion of Idle Proprietors": Madison, Property Rights, and the Abolition of Fee Tail, 58 Wash. \& Lee L. Rev. 167, 169 nn.12-13 (2001) [hereinafter Hart, Fee Tail]. But see Hart, Fee Tail at 169 (arguing that Madison was not as libertarian as portrayed, supporting legislative interference with some forms of property, particularly inherited wealth, to defeat permanency by the equalizing tendency of the laws). 
institutions. Property becomes an experimental space for creating "order without law." 47

Consider practices between neighbors in the private sphere. ${ }^{48}$ It is not necessarily the perniciousness of the state or its tyrannical officeholders that lead people to avoid contact with it. People have other reasons. One is the complexity of formal substantive and procedural rules, which in real life imposes costs for going through state institutions. According to Robert Ellickson, Coasian predictions about when people would resort to the law or avoid it $^{49}$ do not, for example, fit with findings from his study of neighbors in Shasta County, California where transaction costs lead people to ignore law and work things out according to shared informal norms in many instances. ${ }^{50}$ This critique is characteristic of the Liberty of Persons account. Ronald Coase and others who err in assuming that people can "effortlessly learn and enforce their initial legal entitlements" 51 overstate the importance of the law, formal legal institutions, and the state. ${ }^{52}$

Consider, alternately, the intimate spaces of the household. The household is another space in which inhabitants establish order and come up with rules or other means for allocating resources and settling disputes, generally ignoring formal law and state institutions as they go about it. "Liberal households" 53 require, as the background for their activities, several preconditions. One is a "liberal state," a self-restraining or restrained state, limited from intruding into the private sphere, content with "establishing a set of background rules," leaving individuals to "structure their own

47. Some of the impetus for studying "norms" and normative orders outside of formal law in U.S. legal scholarship comes from this school of thought. See, e.g., Robert Ellickson, Order Without Law: How Neighbors Settle Disputes (1991) [hereinafter EllickSON, ORDER]

48. See Robert C. Ellickson, Of Coase and Cattle: Dispute Resolution Among Neighbors in Shasta County, 38 STANFORd L. Rev. 623 (1986).

49. See Ronald H. Coase, The Problem of Social Cost, 3 J. L. \& Econ. 1 (1960) [hereinafter Coase, Social Cost] (in the parable of Farmer and Rancher given to illustrate Coase Theorem, the absence of transaction costs renders law irrelevant).

50. Ellickson, Order, supra note 47, at 280.

51. Id. at 281 .

52. For example, in The Problem of Social Cost, Coase proposes, "In a world in which there are costs of rearranging the rights established by the legal system, the courts, in cases relating to nuisance, are, in effect, making a decision on the economic problem and determining how resources are to be employed." Coase, Social Cost, supra note 49, reprinted in Ronald Coase, The Firm, the Market, and the Law 95, 132-33 (1988), cited in Ellickson, ORDER, supra note 47, at 281.

53. The concept of the "liberal household" is elaborated in William James Boоth, Households: The Moral Architecture of the Economy (1993). 
living arrangements." ${ }^{54}$ Another is a system of private property in land, which "provides havens within which household members can fashion their own domestic arrangements." 55

\section{The Rugged Individualist}

The Liberty of Persons account depends on its own understanding of the human. One is the person occupying state office, the antagonist lurking in the background of Epstein property liberty, the Tyrant. The individual of the private sphere, the protagonist of Epstein and Ellickson property liberty alike, is competent, decisive, and as a matter of cognition better at taking decisions to arrange her own affairs than a third party. ${ }^{56}$ We may call this central figure of the Liberty of Persons account The Rugged Individualist, as long as we understand that individualist to be engaged, often intensely, in private ordering. Our Rugged Individualist is busily involved in privately associating in order to fend off the state or to build up rules and networks for allocating resources and working out disputes over their management. The point is not that the Rugged Individualist is antisocial or apolitical. Rather, she finds political community in private association. As a practical matter, the proximity and scale at which political association happens is usually more local and smaller than the state: the household, the neighborhood, the county. Property in this account may be a topic of discussion, an object of political community; property is certainly the setting for it. Even the Rugged Individualist works on political community, and property plays a central role in its constitution, in the Liberty of Persons account.

\section{B. The Wealth of Nations Account}

Not all see liberty leading to private order, or property necessarily as a space within which order without law is established. The very liberty that affords an individual the authority to devise schemes to co-operate within a household or between neighbors also leaves open the logical possibility of the alternative. Just as we can imagine order without law, we can imagine disorder without law. Autonomous individuals may compete as well as cooperate. Competition for resources raises the specter of disorder and for

54. Ellickson, Household, supra note 44, at 14.

55. Id. at 15 .

56. Id. at 14 ("The core tenet of liberalism is that a competent adult presumptively can decide better than a state, master, parent, or other third party what arrangements best suit that individual."). 
some, this specter becomes a justification for institutions to keep things sorted out. In this vision, property is not the space from which one can achieve respite from the "hurly-burly of larger society" 57 or carve out an autonomy unencroached upon by the state. Rather, in this account property is a prize, the competition for which calls for formal rules and justifies a third-party rule-maker, adjudicator, and enforcer, the state. This account progresses through several steps (some of which-its imagining of a commons, its free-trade conclusions-eventually dominate Western advising to post-Soviet states). ${ }^{58}$ There are a variety of versions, but they begin from a common starting point, the harvest of resources from a commons.

\section{Property, Competition, and Political Community}

The paradigmatic versions of this account, starting with John Locke, open with industrious persons gathering the fruits of nature and, eventually, forming associations to protect their stocks of property from one another. "The great end of men's entering into society, being the enjoyment of their properties in peace and safety" depends on law as "the great instrument and means" in that project. ${ }^{59}$ Thus Locke imagines the origins of state institutions. William Blackstone similarly engages in an imaginary of the origins of human political association. For him, it results from a transition from use rights to ownership rights and from ownership to competition and disputes. In the beginning or shortly thereafter, Mankind's increase demanded a reconceptualization of property, from "immediate use" of objects from the wild commons to "more permanent dominion" over the "very substance of the thing." "Otherwise, innumerable tumults must have arisen, and the good order of the world been continually broken and disturbed, while a variety of persons were striving who should get the first occupation of the same thing, or disputing which of them had actually gained it."60

As fanciful as these imaginative accounts may appear to us now, they are employed as origin myths in the construction of some seri-

57. Ellickson, Household, supra note 44, at 1 .

58. See infra Sections II.B. and II.C. (discussing Western property discourse brought to bear on the post-Soviet reform process).

59. John Locke, Second Treatise of Civil Government ch. 11, § 134 (1690) [hereinafter Locke, Second Treatise], available at https://www.marxists.org/reference/subject/ politics/locke.

60. William Blackstone, Commentaries on the Laws of England 408-09 (W. Maxwell ed., 1865), available at http://books.google.com/books?id=7fhWAAAAcAAJ\&printsec $=$ frontcover\&source=gbs_ge_summary_r\&cad=0\#v=onepage \&q\&f=false. 
ous conceptual apparatuses. In these stories, competition for resources justifies government itself. As Adam Smith asserts in his first lecture on jurisprudence, "The first and chief design of every system of government is to maintain justice; to prevent the members of a society from incroaching [sic] on one anothers [sic] property, or siezing [sic] what is not their own."61 Note that for Smith's individual, the threat of property seizure may come from other private property owners, not only the state.

At this point, the Wealth of Nations account makes a Libertarian point on limiting the use of state power. If government is instituted to protect property, it follows that not even the sovereign or other supreme power may strip a person of her property without her consent. ${ }^{62}$ The American revolutionary slogan "No taxation without representation" illustrates the logical work done by the origin story of laws and state to safeguard property: No state authority may take a person's property without her direct consent or her consent given through a representative. Absent representation, taxation amounts to an annihilation of property rights and works an absurdity, that government annihilates the very thing, property, which it is established to safeguard. ${ }^{63}$ Although they share a position on the necessity of private property being inviolate from government predation, the relationship of the property owner to the state is fundamentally different in the Wealth of Nations account than in the Liberty of Persons account. Instead of property primarily serving as a space of autonomy from the state, property is a claim the state is devised to protect.

\section{The Pay-off: Property as Wealth-Creating Institution}

The Wealth of Nations account offers a vision of the benefits of property rights and the economic activity they support, what Carol Rose calls "the standard story," that property is a wealth-creating institution. ${ }^{64}$ However, this "standard story" actually has at least

61. Adam Smith, Of Jurisprudence (Dec. 24. 1762), LecturEs ON JURISPRUdENCE, vol. V of the Glasgow Edition of the Works and Correspondence of Adam Smith 5 (R. L. Meek, D. D. Raphael \& P. G. Stein eds. 1982), available at http://www.estig.ipbeja.pt/ ac_direito/ Smith_0141.06.pdf.

62. See Locke, Second Treatise, supra note 59, ch. 11, 138 (pointing out property rights between subjects are not secure if a sovereign has the power to seize something, use it, or dispose of it).

63. See, e.g., Arthur Lee, An Appeal to the Justice and Interests of the People of Great Britain in the Present Disputes with America 30 (J. Almon ed., 1775), available at https://archive.org/stream/cihm_36238\#page/n33/mode/2up (quoting Locke's Second Treatise $\S 138$ as the basis for arguing against taxation without representation).

64. Rose, Keystone Right, supra note 4, at 330. 
three different versions in the retelling. One version is that of establishing a claim on property through the labor of first capture. In this story, some resource, sought because of its perceived preexisting value, is up for grabs: a fox, a cave, a record-setting baseball. ${ }^{65}$ One person establishes a superior claim through labor, cunning, first capture. ${ }^{66}$ Adherents of this view, citing to Locke, propose that capturing a contested resource transforms it from an object of undetermined legal status into property. ${ }^{67}$

Second is the story of creating wealth through labor on preexisting property. The resource is not up for grabs. Rather, the question is, what induces a person to work on something that is already her property? Secure property rights create-or rather, are the basis of, in Jeremy Bentham's phrasing-expectation. ${ }^{68}$ The expectation that my claim to a thing will be respected in the future leads me to labor over or cultivate it in the meantime. Here, law fosters the investment of labor into property that creates wealth. ${ }^{69}$ "Law does not say to a man: 'Work, and I will reward you.' It says rather: 'Work, and by staying the hand that would tear them from you, I will assure to you enjoyment of the fruits of your toil . . . . 70 A society that safeguards property rights thus

65. See, e.g., Pierson v. Post, 3 Cai. R. 175, 2 Am. Dec. 264 (N.Y. Sup. Ct. 1805) (allocating disposal of a fox); Edwards v. Sims, 232 Ky. 791, 24 S.W.2d 619 (1929) (regarding rival claims to portions of the Great Onyx Cave); Popov v. Hayashi, No. 400545, 2002 WL 833731, at*1 (Cal. Super. Dec. 18, 2002) (considering rival claims to the baseball hit in Barry Bonds' record-setting 73rd homerun).

66. But see Johnson v. M'Intosh, 21 U.S. (8 Wheat.) 543, 568 (1823) (disregarding prior occupancy in favor of a doctrine of "dominion" to decide rival claims to lands acquired from Native Americans).

67. Locke, Second Treatise, supra note 59, ch. 5, $\$ 27$ (arguing that by removing something from the state of nature, a claimant mixes his labor with it and thereby makes it his property).

68. Jeremy Bentham, Principles of the Civil Code, The Theory of Legislation 145 (Charles Milner Atkinson trans. and ed., 1914), available at http://books.google.com/ books?id=fQg1AQAAMAAJ\&printsec $=$ frontcover\&dq=bentham + principles + of + the + civil + code\&hl=en\&sa=X\&ei=Vi7oU-nMG8PrigKL_YCgDQ\&ved=0CB4Q6AEwAA\#v=onepage\&q= bentham $\% 20$ principles $\% 20$ of $\% 20$ the $\% 20$ civil $\% 20$ code $\& f=$ false (characterizing property as nothing more than the basis of a certain expectation, deriving hereafter certain advantages from a thing which we are already said to possess).

69. Id. at 153 (An attack against one person's property "excites alarm and distrust in property owners generally," while law creates the "encouragement" necessary to the development of industry.). See also Locke, SEcond Treatise, supra note 59, ch. $5 \$ 42$ (wealth accrues to the Prince who secures his subjects' property rights in law and thereby secures "protection and incouragment [sic] to the honest industry of Mankind").

70. Bentham, supra note 68, at 143; see also, e.g., id. at 130. 
increases the wealth of all its members ${ }^{71}$ (even the poorest nonproperty owners).$^{72}$

A third version of property as a wealth-creating institution adds division of labor to the foregoing. Property rights, ensured by a strong third-party guarantor (like the state), provide incentives to labor. The resulting beneficial increases in productivity are further multiplied by division of labor and specialization. ${ }^{73}$ Property thus enriches the individual property owner; it also enriches the economy of which the individual is a part, a key element in producing "the wealth of nations." 74 In an influential addendum to this third version, division of labor may be applied to producing specialized goods according to a nation's "comparative advantage." 75 Instead of accumulating as surplus, that specialized wealth may become a basis for trade, further enriching individuals and nations. ${ }^{76}$ This last version, formulated just after the turn of the nineteenth century, accompanied observation of a shift in property rights and social change ${ }^{77}$ in which property plays a role in the emergence or disappearance of social classes and in political transformation. ${ }^{78}$

These three versions, despite their differences, come to the common conclusion that property creates wealth, which accrues to population and sovereign alike. Property supports both private

71. Id. at 148 ("Now, by creating property, the laws have created wealth . . ..").

72. Id. at 149 (proposing that the protections of property law create wealth for some and thus improve the lot of all, including those still in humanity's original condition of poverty).

73. See Adam Smith, The Wealth of Nations, Vol. I, Book I, § 1.1.1 (the greatest improvement in the productive powers of labor are the effects of the division of labor) [hereinafter SMith, WeAlth of Nations], available at http://www.econlib.org/library/ Smith/smWN1.html\#B.I,\%20Introduction\%20and\%20Plan\%20of\%20the\%20Work.

74. Id.

75. David Ricardo, On the Principles of Political Economy and Taxation ch. 19 $\S 1$ (3d ed. 1821), [hereinafter Ricardo, Principles of Political Economy and TaxaTION], available at http://www.econlib.org/library/Ricardo/ricP5.html\#Ch.19,\% 20 Changes\%20in\%20the\%20Channels\%20of\%20Trade.

76. See David Ricardo, Preface, On the Principles of Political Economy and TaxaTION (1821), available at http://www.econlib.org/library/Ricardo/ricP1.html\#Preface [hereinafter Ricardo, Preface]. But see, e.g., Joan Robinson, Aspects of Development and UNDERDEVELOPMENT (1978) (critiquing Ricardo's theories of comparative advantage and proposals regarding free trade with historical examination of his example of trade between England and Portugal).

77. Ricardo, Preface, supra note 76. See generally, John G. Gagliardo, Enlightened Despotism 39-40, 58-59 (1967) (an old regime of land tenure privileges yielded to a new production model of rural laborers freed from feudal service and a commerce-rich, landless but monied class looking for investments), cited in Rose, Keystone Right, supra note 4.

78. See Gagliardo, supra note 77, at 341 (loosening feudal holds on land tenure and increasing alienability of property in land aided "[e]nlightened [d] espots" competing with traditional landed aristocracies). 
and state spheres; the state secures the private sphere by safeguarding property rights.

\section{The Free-Wheeling Trader}

The figure that emerges from the Wealth of Nations account is the property owner who forms a state to safeguard property interests, the property owner-cum-citizen. Citizens then engage in trading the yields of their properties. The free-market liberalism that finds some roots in nineteenth-century mercantilism envisions a role for the state very different in some respects from Libertarianism. Both share an interest in the state staying out of the way; but while the Rugged Individualist would just as soon the state disappeared, the Free-Wheeling Trader may need the state to safeguard trade, some of which takes place far outside of local normative orders or disputing mechanisms.

The Wealth of Nations account outlined here itself encompasses some positions that would regard each other as intellectual adversaries. However, by the late twentieth century, tensions between a classical economics of national wealth accumulation versus a freetrade economics - so apparent to David Ricardo in the early nineteenth century-had for many become obscured by larger battles with other foes. Even within the West, primary fault lines lay not between Smith and Ricardo, but between Friedman and Keynes. Rather, former distinctions within classical economics had become blurred and property, conceptually, had become lumped into one understanding of what Carol Rose calls "capitalist property rightsfreely acquired, freely traded, divorced from any attachment to birth or status." 79

\section{The Democracy of Nations Account}

In the Liberty of Persons account, property is the basis for a private-sphere refuge from state tyranny, within which private actors order relations amongst themselves without the state. ${ }^{80}$ In the Wealth of Nations account, property is the basis for a wealth-creating private sphere that yields collective enrichment for society and sovereign. ${ }^{81}$ Taken to free-trade conclusions, private production organized around comparative advantage becomes a basis for trade with other nations, further increasing wealth and collective enrich-

79. Rose, Keystone Right, supra note 4, at 337.

80. See infra Section I.A.

81. See infra Section I.B. 
ment. ${ }^{82}$ In the Democracy of Nations account related below, property is still a means, but to a different end: it provides a bulwark against concentrations of power that thwart a people's capacity for self-governance.

\section{Jeffersonian Property Liberty}

This account shares a Libertarian concern with combatting tyranny, but here power is not seen as exclusive to the state. ${ }^{83}$ Wealth may be a source of power as well. Consequently, the private sphere is not only a possible space of resistance against tyranny; with concentrations of wealth, it too may be a source of threat to citizen self-governance. The existence of private property as such is not sufficient to safeguard democratic processes.

This conceptualization of power and risk leads to some programmatic implications. A legal framework supporting private property rights is necessary but not sufficient. The actual arrangement of property also matters. ${ }^{84}$ The "negative" part of this program is that property should not be concentrated in the hands of a few. Concentrations of property could yield concentrations of wealth used to influence democratic deliberations, sway governance processes, or control state offices. The "positive" part of this program is that property distributed among small-holders can reinforce the potential for self-governance by providing a base for economic self-suffi-

82. See infra Section I.B.2.

83. For the view of a representative early radical Jeffersonian, see, e.g., Michael Lieb, Medical Doctor of Philadelphia and Advocate of Republican Government, Aurora (Nov. 2, 1801) (under despotism, people's property, liberty, and lives are held "by courtesy," not by law), cited in Andrew Shankman, Malcontents and Tertium Quids: The Battle to Define Democracy in Jeffersonian Philadelphia, 19 J. of the Early Republic 43, 46 (1999).

84. To take just one famous example, Jefferson worked to divorce bloodline from land holding by trying to abolish the fee tail in the United States. See A.W.B. Simpson, A History OF THE LAND Law 81-82, 90 (2d ed. 1986). Fee tail was an inheritable estate in land that could not be alienated in fee simple by the present possessory interest holder (the "tenant in tail"). See id. It passed at death to the heir in tail, typically by primogeniture. See id. If the bloodline died out, absent remaindermen, the reversion interest determined present possessory interest meaning that at that point rights in land reverted to the grantor (or, more likely, grantor's heir) in fee simple. See id. See also J. of the House of Delegates of VA. [Oct. 7-Dec. 21, 1776] at 13, 23 (Richmond, Samuel Shepherd 1821) (reporting that Jefferson presented the bill to abolish fee tail in Virginia), cited in Hart, Fee Tail, supra note 46, at 168 n.4; Thomas Jefferson, Autobiography, in 1 The Writings of Thomas Jefrerson 68-69 (Paul Leicester Ford ed., New York, G.P. Putnam's Sons 1892) (asserting the importance of abolishing fee tail and counting the Virginia legislation among his foremost achievements), cited in Hart, Fee Tail, supra note 46, at 168 n.4; Act of Oct. 1776, ch. XXVI, 9 The Statutes at Large: Being a Collection of All the Laws of Virginia 226 (William Waller Hening, ed., Richmond, Va., J. \& G. Cochran 1821) (abolishing fee tail), cited in Hart, Fee Tail, supra note 46, at 167 n.1. 
ciency and thus resistance to wealthy or politically powerful interveners. This view of the relationship between property and political community, wherein the goal is the Democracy of Nations over the Wealth of Nations, is most famously associated with Thomas Jefferson. ${ }^{85}$

\section{Property, Subsistence, and Civic Virtue}

Jefferson relies on property to furnish the property-owning citizen with subsistence. Economic self-sufficiency in turn provides the possibility of citizens independent from the pressure of wealthier or larger interests during deliberations required of democratic self-governance. Land ownership does not accomplish all that Jefferson expects of property. Land use plays a role as well. Jefferson's contemporaries observe traditional agricultural production in Britain giving way to three new classes: land owner, agricultural laborer, and (potentially landless but monied) commercial investor. ${ }^{86}$ That sort of alienation does not suit Jefferson's purposes. His account connects political economy with moral economy. For Jefferson, land use plays a role in the formation of citizens adequate to a functioning democracy. "Cultivators of the earth are the most valuable citizens," 87 he asserts, again and again. ${ }^{88}$ Property ownership in land forges lasting bonds to a nation in a time of emigration, immigration, nation-building, loyalty, and betrayal. ${ }^{89}$ It is not agricultural land in its symbolic capacity that most captures Jefferson's imagination, however. In his view, the activity of farming instills a prized kind of civic virtue. ${ }^{90}$ Agriculturalist landown-

85. See generally Richard Hofstadter, The Age of Reform: from Bryan to FDR (1955).

86. See Ricardo, Preface, supra note 76; for an influential treatment, see also Charles A. Beard, Some Economic Origins of Jeffersonian Democracy, 19 Aм. Hist. Rev. 282, 298 (1914) (characterizing the split between Hamilton's Federalists and Jefferson's Republicans in Congress as "a clear case of a collision of economic interests: fluid capital versus agrarianism.”).

87. Letter from Thomas Jefferson to John Jay (Aug. 23, 1785), in Writings of Thomas JefFerson 818 [hereinafter JefFerson, Letter to Jay], cited in Michael Hardt, Jefferson and Democracy, 59 Ам. Q. 41, 54 (2007) [hereinafter Hardt, Jefferson and Democracy].

88. See, e.g., Thomas Jefferson, Response to Query XIX, The Present State of Manufactures, Commerce, Interior and Exterior Trade?, in Notes on the State of Virginia (1787 (1781) ) [hereinafter JefFErson, Notes ON Virginia], available at http://avalon.law.yale.edu /18th_century/jeffvir.asp ("Those who labour [sic] in the earth are the chosen people of God, if ever he had a chosen people").

89. JefFerson, Letter to Jay, supra note 87 (cultivators are "tied to their country \& wedded to it's [sic] liberty \& interests by the most lasting bonds.").

90. Id. (affirming farmers are "the most vigorous, the most independent, the most virtuous" citizens). 
ers are a repository for "genuine virtue" because they "look up to heaven, to their own soil and industry" for subsistence. ${ }^{91}$

The alternatives suffer by comparison. In Europe, lands are "locked up against the cultivator" because of scarcity of arable land or because of local monopolies on ownership. ${ }^{92}$ The resulting unemployment might reasonably lead European political economists like Smith to preach manufacture; but with different land tenure regime and population density America is freed to construct a system of land ownership that fosters the moral character of a citizenry necessary for democracy. Those who labor in manufacturing depend on the "casualties and caprice of customers." ${ }^{3}$ "Dependance [sic] begets subservience and venality, suffocates the germ of virtue, and prepares fit tools for the designs of ambition." 94 These are not qualities of citizens fit for self-governance. His writings to Washington betray skepticism of a Ricardian economy based on trade as well. ${ }^{95}$ In aggregate, the health of a citizenry can be measured by the proportion engaged in agriculture. ${ }^{96}$

It is this anthropology-an understanding of human nature that construes a causal relationship between land ownership, the selfsufficiency of subsistence agriculture, and a resultant civic virtueand its sociological conclusions that take Jefferson to a theory of government and political economy. He fears the nation's dependence on a raw-materials export economy less than he fears the loss of the individual's self-sufficiency and economic independence that a manufacturing economy would bring about. "[L] et our work-shops remain in Europe. It is better to carry provisions and materials to workmen there, than bring them to the provisions and materials, and with them their manners and principles." 97

Despite his totemic status in U.S. history, Jefferson's economic views are out of fashion. This is not only because of repugnance at the contradiction between his views on property, virtue, and democracy and his own practices in using enslaved labor to cultivate his agricultural land. In addition, today Jefferson's calls for an

91. Jefferson, Notes on Virginia, supra note 88. Jefferson wrote his "Notes on the State of Virginia" as an analytical response to queries from a French interlocutor in which he explains natural resources and political economy of his corner the new world. $I d$.

92. $I d$.

93. Id.

94. Id.

95. See, e.g., Thomas Jefferson, Letter to George Washington (Aug. 14, 1787), available at http://founders.archives.gov/documents/Jefferson/01-12-02-0040.

96. JefFerson, Notes on Virginia, supra note 88.

97. Id. 
economy based on extraction, agriculture, and export of raw materials versus manufacturing and commerce look like the basis of what is now called "underdeveloped" versus "developed" economies. ${ }^{98}$ In economic development his opponent Alexander Hamilton is cited today as having anticipated a future course of American capitalism. ${ }^{99}$ However, in their own time, rivals did not reduce the Republican-Federalist debates to a dispute over economic production. Their views differ in political theory, sociology, and anthropology: over the plausibility of different forms of representative government, the kind of social structure required for it, and the kind of persons who would make the citizens demanded of that society and government.

Jefferson does not claim that this program promises greatest efficiency. His eye is on a higher prize. "The loss by the transportation of commodities across the Atlantic will be made up in happiness and permanence of government." 100 His calculation is based on the "spirit of a people" required for a healthy democracy. Neither wealth itself, nor a tyranny-restraining constitution, nor wise legislation are enough to preserve the republic. "It is the manners and spirit of a people which preserve a republic in vigour [sic]. A degeneracy in these is a canker which soon eats to the heart of its laws and constitution."101

\section{The Self-Sufficient Citizen}

The central figure of the Democracy of Nations account is the Self-Sufficient Citizen, yeoman-farmer, autarkic, unencumbered by dependency and immunized against wealthier or more powerful influences. Small-holding agriculture offers the self-sufficiency that protects against the tyrant and his state as well as against the oligarch and his manipulations of wealth. ${ }^{102}$ Just as importantly in Jefferson's view, it cultivates a certain independence of character that a democracy requires in its citizens.

98. Hardt, Jefferson and Democracy, supra note 87.

99. Id. at 54 .

100. JefFerson, Notes on Virginia, supra note 88.

101. Id.

102. C. B. MacPherson, Democratic Theory 135 (1973) (in Jeffersonian thought, small property defies subservience and guarantees against government tyranny and economic oppression), cited in Hardt, Jefferson and Democracy, supra note 87, at 57 n.18. For critique of Jefferson's "reactionary utopia” of agrarianism, see MANFredo TAFURI, ArCHItecture And Utopia (BarbaraLuigia LaPenta, trans., 1979), cited in Hardt, Jefferson and Democracy, supra note 87, at 54 n.16. 
Jeffersonian economic theory had long lost currency with U.S. legal theorists by the end of the twentieth century, yielding to preoccupations with increasing wealth or maximizing utility. Although not in vogue as economic theory, though, Jeffersonian documents and the liberties they espouse figure in the celebratory atmospherics at the fall of the Berlin Wall and the dissolution of the Union behind the Iron Curtain. At that time, too, in U.S. scholarship and policy advising to Eastern European governments, a Jefferson presumption of a relationship between property owner and model citizen resurfaces, I propose, sometimes explicitly ${ }^{103}$ and sometimes implicitly. ${ }^{104}$

\section{Legal Thought on the Eve of Engagement}

In this section I identify several accounts in Western legal scholars' intellectual repertoire as they faced the challenges of the postSoviet moment. As different as these accounts are from each other, they share some commonalities. In each, property-a feature of a private sphere-plays a distinctive role in the constitution of political community, the ordering of social relations in a certain kind of public sphere. The central figure emerging from each account is the figure of the private property owner, imagined as an individual. Property is the setting for a private sphere; it creates wealth or self-sufficiency, either enriching the nation or empowering individuals to create self-governance.

This material also highlights major questions, dating at least to the founding of the U.S. republic, still left unresolved. Is property the basis for a private sphere that is an indispensible space for political associations below the radar of the state or source of concentrations of wealth that add one more threat to citizen self-governance? Does property bring empowering self-sufficiency or disempowering differences in wealth? New questions arise: How would the Self-Sufficient Citizen fare in a time of modern industrialized agriculture and economies of scale? Finally, while the traditions upon which these accounts draw do attend to the practicalities of citizen self-governance, in their late twentieth-century versions broadcast to former socialist states, democracy is surprisingly underexplained. Is democracy merely a matter of how rulers are selected, amounting to holding free and fair elections?

103. See, e.g., Sunstein, supra note 13.

104. See infra Section II.C. 
Or is democracy a matter of citizen self-rule, and if so, what would that specifically look like in today's world?

With these accounts furnishing explanations, informing conscious critique and subconscious expectation, Western property theorists viewed a landscape newly revealed with the raising of the iron curtain. Section II explores features of that exposed landscape. It describes property in Marxist theory, Soviet doctrine, and socialist practice, an alternative account and history from which a different figure emerges. Western critique of Soviet practice, based on Western intellectual histories, gave rise to diagnosis of a property problem and a property solution for the post-Soviet condition. Some results of the encounter between Western ideas and post-Soviet experience are reported in Sections III and IV.

\section{Diagnosis And Remedy \\ A. Constructing a Collective}

\section{Marxist Theory, Soviet Doctrine}

Socialism is, in important part, also a set of ideas about how property regime effects social relations and belief systems. Rose's "standard story" that property creates wealth ${ }^{105}$ is not the one told here. Instead, classical Marxism identifies private property as the mechanism that turns laborers into proletarians, the cause of exploitation under capitalism, and the key element of a capitalist mode of production. ${ }^{106}$ With the abolition of private property a central tenet of Bolshevik doctrine, the legal status of property was central to the Soviet Socialist project from its beginnings. ${ }^{107}$ As one of its first acts, the Soviet government redistributed crown and church estates to local peasants. ${ }^{108}$ Eradicating private ownership

105. Rose, Keystone Right, supra note 4. See also infra Section II.B.2 (discussing three versions of property as wealth-creating institution).

106. See, e.g., 1 Karl Marx, Capital ch. 32, The Historical Tendency of Capitalist Accumulation (Samuel Moore \& Edward Aveling, trans., 1887), available at http://www.marxists.org/ archive/marx/works/1867-c1/ch32.htm.

107. See, e.g., Decree of All-Russian Central Executive Committee, On Socialist Land Reform and on Measures Leading to Socialist Farming, Sobr. Uzakon. i Rasporiazh. RKP RSFSR [Collection of the Laws and Orders of the Worker-Peasant Government of the Russian Soviet Federated Socialist Republic], 1919, No. 4, Item 43 (reaffirming, shortly after the revolution, intention to outlaw individual types of farming and setting collective land use as the destination for Soviet law and policy), reprinted in IDEAS AND Forces IN SOVIET Legal History 118 (Zigurds L. Zile ed., 1992) [hereinafter Zile, Soviet Legal History]; see also Vladimir Ilyich Lenin, Otvet na zapros krestianina [Reply to a Peasant's Inquiry], in Polnoe Sobranie Sochinenir [Complete Collection of Essays], 1953 (1919).

108. See Second All-Russian Congress of Soviets Decree "On Land," Sobr. Uzakon. i Rasporiazh. RKP [Collection of the Laws and Orders of the Workers' and Peasants' Gov- 
in all agricultural lands, including small peasant holdings, began with mass collectivization a decade later. ${ }^{109}$

By the end of the Soviet period, Soviet law had erected a hierarchy in which property at each level enjoyed a different extent of legal protection. The more accessible to the public or reciprocal the relations between users, the higher in the hierarchy a category stood. At the top, "state socialist property" included property specifically owned by the state, all land, and all natural resources. It could not be used as security and was inalienable.110 It was followed by "cooperative property," a kind of restricted-use commons, belonging indivisibly to a distinct group of citizens. ${ }^{111}$ At the bottom of the hierarchy, "personal property" served personal needs and included single-family apartments or houses, dachi (vacation cottages), furniture, clothes, and cars. ${ }^{112}$ (Ownership of a house or dacha did not include the land under the building. Translating into Anglo-American terms, we could say roughly that Soviet law lacked fixtures doctrine and treated buildings more like personalty than realty.) ${ }^{113}$ Personal property was the only freely transferable property, but its use for profit-making activities was largely outlawed. ${ }^{14}$ Presumptions of legal protection were reversed from those in the West: the more private the claim, the less legal protection it enjoyed. In other words, the lower a property type stood in the hierarchy, the more vulnerable a particular holding was to confiscation, regulation, taxation, or counter-claim. The category of private property was abolished altogether. ${ }^{115}$ Productive assets were "state property, i.e. the common property of the Soviet people." 116

Under this schema two entities were allowed to hold agricultural land: the state farm (sovkhoz), in which land and capital equipment belonged to the state, and the collective farm (kolkhoz), a restricted-

ernment] 1917-1918, No. 1, Item 3, reprinted in Zile, Soviet Legal History, supra note 107, at $116-17$.

109. See infra Section II.A.2.a.

110. See Victor P. Mozolin, Property Law in Contemporary Russia 10 (1993) [hereinafter Mozolin, Property Law].

111. W.E. Butler, Soviet Law 178-79 (1983) [hereinafter Butler, Soviet Law].

112. See Mozolin, Property Law, supra note 110, at 10-11.

113. See F.J.M. Feldbrugge, Russian Law: The End of the Soviet System and the Role of LAW 229-46 (1993).

114. See Butler, Soviet Law, supra note 111, at 174.

115. See Heller, Anti-Commons, supra note 13, at 628-29.

116. Konst. SSSR (1977) [USSR Constitution], art. 11 ("State property, i.e. the common property of the Soviet people, is the principal form of socialist property. The land, its minerals, waters, and forests are the exclusive property of the state. The state owns the basic means of production in industry, construction, and agriculture ...."). 
use commons to which the collective held title and in which userights to the land and equipment belonged indivisibly to the workers. ${ }^{117}$ Resident workers on a state farm were wage laborers with steady income. ${ }^{118}$ Members of a kolkhoz, working collectively-held property, were subject to risks of weather, pests, disease, and other exogenous hazards of agricultural production. Insiders felt the difference. Neither state farms nor collective farms could legally sell land. ${ }^{119}$ Although a barter market in equipment and unauthorized land use did arise, bargaining was curtailed by central planners' control over allocation of inputs and price of outputs. ${ }^{120}$

This difference in lived experience between state and collective farm is one point where assumptions embedded in Western property scholarship obfuscate an important distinction, giving rise to blind spots or misunderstanding. Much of Western scholarship neglects the category of "state property." Harold Demsetz gives just a one-sentence definition in his theory of property. ${ }^{121}$ Others do not think it warrants even that ${ }^{122}$ or elide state property with the category of collectively-held property. ${ }^{123}$

For our analysis, we retain separate categories of state and collective property for several reasons, the first being ethnographic accuracy. ${ }^{124}$ The old de jure distinction between state and collective ownership survives into the present in some rural practices, pat-

117. See Model Collective Farm Charter, 10 Spravochnik Partinogo Rabotnika ("Handbook of the Party Worker") 175 (1970), cited in Donald D. Barry, The Spravochnik Partinogo Rabotnika as a Source of Party Law, in Ruling Communist Parties and Their Status Under Law 37, 45 (Dietrich A. Loeber ed., 1986).

118. See Merle Fainsod, How Russia is Ruled (1967).

119. See C.P.W., Collective Farming in the U.S.S.R.: Post-War Consolidation of Control, 470, 470-71 IV The World Today (Nov. 1948) [hereinafter Collective Farming in the U.S.S.R.].

120. See, e.g., id. at $475-76$

121. Harold Demsetz, Toward a Theory of Property Rights, 57 Am. Econ. Rev. 347, 354 (1967) [hereinafter Demsetz, Property Theory] ("State ownership implies that the state may exclude anyone from the use of a right as long as the state follows accepted political procedures for determining who may not use state-owned property.").

122. See, e.g., Robert Ellickson, Property in Land, 102 Yale L. J. 1315, 1322 (1992-93) [hereinafter Ellickson, Property in Land] (querying why Demsetz singles out the state as a different form of ownership entity and asserting when government acts in a proprietary role as a land manager, it shares attributes with a nongovernmental group with a constituency of comparable size).

123. Although Dagan and Heller admit the state has a special status, in the end they come around to something like Ellickson's position dismissing the category of state property, surmising since demise of socialism, it has so lost importance as to warrant dropping it from the previous normalized trilogy of property categories (private, commons, and state). See Hanoch Dagan \& Michael Heller, The Liberal Commons, 110 Yale L.J. 549, 558 (2000-01) [hereinafter Dagan \& Heller, Liberal Commons].

124. Even when all agricultural land in post-Soviet Ukraine had been converted to collective ownership, it took specific legal measures to extinguish state ownership. See infra 
terns of relationships, epistemology, and expectations. A second reason pertains to its analytic utility. The category of "state property" foregrounds a peculiar owner/manager enjoying unusual authority to tax, regulate, and exercise powers of eminent domain. ${ }^{125}$ These peculiar powers of regulation - including the capacity to criminalize certain uses or users - belong singularly to the state and hold particular explanatory power. (We do this understanding that "the state" itself is not an unproblematic or simple category, standing for decidedly varied forms of organization and practice.) The state actually occupies two positions in our property analytic: in the analytic category of property owner, theoretically positioned the same as other owners but in practice endowed with different levers of power, and at the same time in a separate category that subsumes others, as the institutional setting in which all other property is held. These distinctions may seem like splitting hairs until we need to analyze situations of public-private overlap or oligarchy. Finally, we preserve the conceptual category because compared with state property, collective property has several distinct features. Collective property most closely approximates Demsetz's category of communal ownership, ${ }^{126}$ for reasons of scale its management often subject to relations that are, in Nader's term, face-to-face as opposed to face-to-faceless. ${ }^{127}$ The nature of the group also matters. Collectively-held property supports forms of the self and the social not based primarily on state forms of selfhood (like, for example, citizenship), sociability (for example, bureaucratic indifference), ${ }^{128}$ or ethical systems predicated on state values (like, for example, patriotism). Quality as well as quantity of in-group relationships make a difference regarding managing a shared resource; the state/collective distinction captures some of those qualitative differences.

Marxist theory and Soviet legal doctrine create a framework for action. That action, i.e. implementation of theory and doctrine, is briefly described in the next section in order to describe the land-

Section IV.A. (describing legal measures to abolish state farms and convert them into collective farms).

125. See Ellickson, Property in Land, supra note 122, at 1322.

126. Demsetz, Property Theory, supra note 121, at 354.

127. See Laura Nader, The Life of the Law: Anthropological Projects 11, 55, 172 (2002). See also Laura Nader, A User Theory of Law as Applied to Gender, in The Nebraska Symposium in Motivation: The Law as a Behavioral Instrument (1985) (arguing that development of the law is driven by plaintiffs and explaining that differences of scale and density of social relations matter in that project).

128. For exploration of bureaucratic indifference as a feature of the modern state, see Michael Herzfeld, The Social Production of Indifference (1993). 
scape and legacies they created upon which Western property theories would later be brought to bear.

\section{Socialist Practice}

\section{a. Collectivization as Destruction}

Establishing collective land ownership in Ukraine after the Soviet Revolution entailed two steps. The first step, what is commonly termed "collectivization" in the West, involved destruction of the previous land tenure system and elimination of a relatively well-off (in a context of poverty) rural demographic group, the socalled "kulaks."129 Between December $1927^{130}$ and March 1930,131 Party and government leaders first urged, ${ }^{132}$ then directed, rural households to form collective farms. ${ }^{133}$ In parallel, authorities hardened their stance towards kulaks. Initially singled out for economic isolation, ${ }^{134}$ kulaks became the target of "'liquidation' as a class," a campaign that chillingly became known as "dekulakiza-

129. "Kulak" was a subjective term, designating relatively better off rural smallholders. How prosperous a person needed to be to be considered a kulak depended on how poor his or her neighbors were: in one village, owning draft animals could make one a kulak while in another, merely owning a pig might be sufficient. Judgment was local; during collectivization, village committees of poor peasants were to draw up lists of local "kulaks." Monica E. Eppinger, Reforming the Nation: Law and Land in Post-Soviet Ukraine (2010) (unpublished Ph.D. dissertation, University of California, Berkley).

130. See Fifteenth Congress of the All-Union Communist Party (Bolshevik) stenographic record 56 (1928) [hereinafter Fifteenth Congress], cited in WAR Against the Peasantry, 1927-1930, Volume 1: The Tragedy of the Soviet Countryside 386 n. 24 (Lynne Viola et al. eds., 2005) [hereinafter Viola, Tragedy of the Soviet Countryside].

131. See I.V. Stalin, Dizzy with Success: Concerning Questions of the Collective Farm Movement, Pravda, Mar. 2, 1930, at 2.

132. See Viola, Introduction to Chapter 3, The Great Turn, 4 May 1929 - 15 November 1929, in Viola, Tragedy of the Soviet Countryside, supra note 130, at 122 (only 1.7\% of peasant households voluntarily joining in the first six months).

133. See Decree of the Central Committee of the Communist Party "On the Pace of Collectivization and State Assistance to Collective-Farm Construction,” January 5, 1930, KPSS v Resolutsiakh i Resheniakh S'ezdov, Konferentsiakh, i Plenumov TsK [The Communist Party of the Soviet Union in Resolutions and Decisions of Meetings, Conferences, and Plenums of the Central Committee], vol. 5, 72-75 (declaring "wholesale" collectivization of no less than $75 \%$ of a every village), reprinted in Viola, TRAGEDY OF THE Soviet Countryside, supra note 130, at 201-03.

134. Decree of USSR Central Executive Committee and the Council of People's Commissars "On Collective Farms," Sobr. Zakon. i Rasporiazh. RKP SSSR [Collection of Laws and Orders of the Worker-Peasant Government of the Union of Soviet Socialist Republics] 1927, No. 15, Item 161 (excluding kulaks from purchasing agricultural machinery on favorable terms, forbidding "pseudo-cooperatives" of kin). See also Fifteenth Congress, supra note 130, at 60 (Stalin advocating "economic measures" to limit the "the known growth of the kulak" in December 1927 at the Fifteenth Congress of the All-Union Communist Party). 
tion." 135 Between January and March of 1930, Party leaders in Moscow sent urban members and local agents to confiscate kulak property and summarily execute, incarcerate into concentration camps or exile kulak owners, and resettle any survivors on small plots excluded from the new collectives. ${ }^{136}$ Dekulakization fell particularly hard on Ukraine. The authorizing decree set quotas for concentration camp incarceration and exile per republic, with the quota for Ukraine two to six times higher than for all other regions. ${ }^{137}$ Between exhortation of rural households and dekulakization, the portion of collectivized farmland in Ukraine rose from $16 \%$ to $64 \%$ in three months. ${ }^{138}$

Dekulakization depopulated pockets of the countryside. For those left behind, an ominous indicator of worse times to come initially went largely unnoticed: the first socialized farms, expected to provide only $12.7 \%$ of national grain demand under the 1929 agricultural plan, fell short even of that modest goal. ${ }^{139}$ In 1931, crop yields fell dramatically, but unbelieving Soviet authorities continued to order aggressive grain confiscation even though farmers did not have a surplus. ${ }^{140}$ By spring 1932, some peasants were already too hungry to work in the fields. ${ }^{141}$ By summer, Ukrainian peasants were committing suicide to avoid starvation and the Soviet secret police (the KGB-predecessor Obyedinyonnoye Gosudarstvennoye Politicheskoye Upravleniye (OGPU)) was sending scattered reports of cannibalism back to Moscow. ${ }^{142}$ While thousands

135. See Politburo Decree "On Measures for the Liquidation of Kulak Farms in Raions of Wholesale Collectivization," Jan. 30, 1930 (Russian Government Archive of Social and Political History f. 17, op. 162, d. 8, 1l. 64-69), reprinted in Viola, Tragedy of the Soviet Countryside, supra note 130, at 228-34.

136. Id.

137. See id. (targeting 15,000 Ukrainians for concentration camps and 30-35,000 for exile as kulaks).

138. See id.

139. See R.W. Davies, The Socialist Offensive: the Collectivization of Soviet AgriCULTURE 1929-1930, 104-05 (1980).

140. See The 1931 Grain Harvest, in R.W. Davies and Stephen G. Wheatcroft, The Years of Hunger: Soviet Agriculture, 1931-1933 48-78 (2004). On food security in the U.S.S.R., see generally Elena Osokina, Our Daily Bread: Socialist Distribution and the Art of Survival in Stalin's Russia, 1927-1941 (Kate Transchel ed. \& trans., Greta Bucher Trans., 2001) (abridged and edited version of Elena Osokina, Za Fasadom "STalinskogo IZOBILIIA": RASPREDELENIE I RYNOK v SNABZHENII NASELENIIA v Gody INDUSTRIALIZATSiI 1927-1941 63-64 (1999).

141. See generally Lynne Viola, Introduction, in Viola, Tragedy of the Soviet CountrySIDE, supra note 130 , at 1-20.

142. See, e.g., "Cases of Cannibalism in Uman district, Kiev Region," Special Communication of Deputy Head of the Ukrainian GPU, January 28, 1932, TsDAGOU [Central Government Archive of Civil Organizations [Unities] of Ukraine] f. 1, op. 20, 1. 6274, 32; Kiev GPU Report March 12, 1932, in Holod, 1932-33 (Kiev, 1990) 433-37; GPU Report from 
of kulaks had been killed and tens of thousands more exiled during collectivization, the worst losses during the destructive phase of Ukrainian collectivization came from hunger.

In Sen's analysis, famine causes death either by food availability decline [FAD] (a net loss of foodstuffs available to a consumer) or food entitlement decline [FED] (wherein food exists but hungry people's access to it has declined to starvation levels). ${ }^{143}$ Ukrainian villagers in 1931-1933 certainly suffered from food availability decline, as harvests faltered from dislocation of hundreds of thousands, the violent interruptions of collectivization, and the loss of managerial expertise and normative order from dekulakization. More, however, died from food entitlement decline, from policy decisions in Moscow to strip the Ukrainian countryside of grain to export or to feed urban workers. Of a Soviet Ukrainian population of 33 million, a minimum estimate of 3.5 million starved to death between 1932 and 1933.144 Within two harvests of decollectivization, a minimum of $10 \%$ of the total population of Soviet Ukraine had perished. ${ }^{145}$

Thus "collectivization" in Ukraine typically refers to a brief, catastrophic three-year period of change in rural land ownership between 1929-1932 at the cost of more than 10\% of the rural population. These general outlines of the destructive phase of Ukrainian collectivization, familiar to U.S. thinkers, influenced their interpretation of the Soviet experience and post-Soviet reform. However, collectivization in its overtly destructive phase was only the first step. In rural Soviet Ukrainian experience, "collectivization" in its constructive phase continued over the subsequent five decades.

Dnipropetrovsk, March 5, 1932, in Holod, 1932-33 409 (Kiev, 1990); Report of Information and Sowing Group of Ukrainian Party Central Committee, April 1, 1933, in Holod, 1932-33 480-81 (Kiev, 1990); all discussed in R.W. Davies \& Stephen G. Wheatcroft, The Years of Hunger: Soviet Agriculture, 1931-1933 421-22 (2004).

143. See Amartya Sen, Poverty and Famines: an Essay on Entitlement and DeprivaTION (1981).

144. Total registered deaths (which likely reflects under-reporting) for 1931-33 in Ukraine is 3,091,809, reflected against an estimated 1930 population of 28,710,628. See R.W. Davies' latest calculation at www.soviet-archives-research.co.uk/hunger. Davies and Wheatcroft, adjusting for statistical birth and death rates, add to the death toll an estimated 1.54 million "excess deaths," i.e. people who died from famine who would not otherwise have died at that time, in 1932-1933 alone in Ukraine. See R.W. Davies And Stephen G. Wheatcroft, The Years of Hunger: Soviet Agriculture, 1931-1933 415 (2004).

145. See generally Hunger by Design: The Great Ukrainian Famine and Its Soviet ConTEXT (Halyna Hryn ed., 2008). 


\section{b. Collectivization as Construction}

As James Scott observes, collectivization ordered rural populations in such a way that they became visible to the state. ${ }^{146}$ It also re-ordered agricultural production with profound effects on political community locally. ${ }^{147}$ Collective farms were to operate as a unit, not merely as an agglomeration of lands held in group ownership. And so, after its violent inception, another extraordinary movement is associated with Soviet collectivization: building a modern collective life. Here I highlight just a few measuresapplication of science; standardization; division of labor; specialization; and industrialization-that transformed collectivized farms and labor:

Science: To facilitate the application of science to agricultural work, the Soviet government began with the basics, introducing mass literacy ${ }^{148}$ through new institutions like the "rural reading room" 149 for volunteers to teach adult reading or disseminate information inter alia on agricultural science. ${ }^{150}$ Learning to read became not merely a personal pursuit, but a "social task," 151 creating readerships through which common bodies of scientific knowledge circulated. ${ }^{152}$

146. James C. Scott, Seeing Like a State 203 (1998) (the Soviet state's "great achievement" in collectivization was "to take a social and economic terrain singularly unfavorable to appropriation and control and to create institutional forms and production units far better adapted to monitoring, managing, appropriating, and controlling from above").

147. Contra Sсотт, id. at 202-03 (alleging Soviet collectivized agriculture was an "evident failure" in raising grain production, creating "new men and women" in the countryside, or abolishing cultural difference between country and city).

148. Before collectivization, an "army" of twelve million illiterates had blocked agricultural development because the troops could not read the latest scientific literature on farming methods. See 3 Rabotnik Prosveshchenita [Worker of Enlightenment] 22-23 (1926), cited in Charles E. Clark, Uprooting Otherness: The Literacy Campaign in NEPEra Russia 131 (2000) [hereinafter Worker of EnLightenment].

149. I. Kuz'min, Kak organizirovat' i postavit' rabotu izbY-chital'ni [How to Organize and Set to Work a Rural Reading Room] 54-55 (1926), cited in Charles E. Clark, Uprooting Otherness: The Literacy Campaign in NEP-Era Russia 118 (2000).

150. See, e.g., Worker of Enlightenment, supra note 148 (instructing and encouraging volunteers in early rural literacy campaigns of the 1920s).

151. Editorial introduction to Nadezhda Krupskaya's "The Organization of Self-Study," in N.K. Krupskaya, Pedagogicheskie Sochinenie v Shesti Tomakh, Tom Vtoroi [PedagogiCAL Essays IN Six Volumes, Vol. II] 418 (trans. my own, Pedagogika, 1978) (“[D]eveloping socialist society and scientific-technical revolution" demands "constantly renewing the knowledge of every member of society" which itself is "an important social task.").

152. For an analysis of some effects of creating a reading public, see generally BENEdict Anderson, Imagined Communities: Reflections on the Origin and Spread of Nationalism (2006). 
Standardization: Training sessions standardized agricultural techniques within and across farming communities. ${ }^{153}$ "Comrades' courts" provided a forum where fellow farmworkers could reinforce norms of "tempo, quality, and quality control," i.e., mutually monitor standardization. ${ }^{154}$ Widespread adoption of mechanized farming - produced in a limited range of models - reproduced standardization in material culture, from the width of crop rows to the size of milk bottles.

Division of labor and specialization ${ }^{155}$ : A grass-roots campaign, the Stakhanovite movement ${ }^{156}$, applied Taylorist methods ${ }^{157}$ to increase productivity. Borrowing from a movement that began in Ukrainian coal mining and heavy industry, rural Stakhanovites strove to bring rigorous self-discipline, mechanization, division of labor, and specialized knowledge to fellow collective farm workers. ${ }^{158}$ Such efforts sought to divide up agricultural tasks and train peasants accordingly, creating specialized workers per task. This division of labor recalls Durkheim ${ }^{159}$ more than Ricardo, ${ }^{160}$ functioning as a source of social solidarity rather than comparative advantage.

Enduring legacies of the collectivized countryside resulting from socialist legal doctrine and policy, then, include rural veneration of scientific learning, interest in cutting-edge "best practices," and a scientific division of labor aimed at maximizing individual efficien-

153. Reading itself is a technology of standardization, of course.

154. See, e.g., 9-10 Za tempy, kachestvo, proverku [For tempo, quality, and quality control] 35 (1933), photo reportage reprinted in Oleg Kharkhordin, The Collective and the Individual in Russia: A Study of Practices 281 (1999) [hereinafter Kharkhordin, Collective and The Individual].

155. For description of collective farms patterned on the labor practices of heavy industry, see R.W. Davies, The Industrialization of Soviet Russia, vol. 2, The Soviet Collective Farm, 1929-1930 (1980); Sheila FitzPatrick, Stalin's Peasants (1994).

156. See, e.g., Lewis H. Siegelbaum, Stakhanovism and the Politics of Productivity IN THE U.S.S.R, 1935-1941 (1988).

157. For the importance of Taylor in Soviet modernization practices, see, e.g., Nadezhda Krupskaya, The Organization of Self-Study, Chto Chitat' i chemu UChIT'sya, [What to Read and why to study] (1922), reprinted in N.K. Krupskaya, Pedagogicheskie Sochinenie v Shesti Tomakh, Tom Vtoroi [Pedagogical Essays in Six Volumes, Vol. I] 132, 132 nn.1, 132 and nn.4, 5, 7, 8, 11 (1978) (by Lenin's widow and an influential Party activist; citing as models pragmatist William James, and Frederick Taylor, the American engineer who conceived a system for maximizing efficiency during the workday).

158. See, e.g., Mary Buckiey, Mobilizing Soviet Peasants: Heroines and Heroes of Stalin's Fields 115, 119 (2006) ("Stakhanovites had a duty to share information on better performance in order to boost food production.").

159. See Emile Durkheim, The Division of Labor in Society (1893).

160. See Ricardo, Principles of Political Economy and Taxation, supra note 75 , ch. $19 \S 1$. 
cies in group organization through specialization, routinization, and spatial arrangements. The collective farm became organized much like an urban factory than a collection of Jeffersonian yeoman-individualists. Collectivization throughout the Soviet economy intensified in the late $1950 \mathrm{~s} .{ }^{161}$ On farms, a new administrative organ, the "link," united existing primary labor units into a single group of agricultural brigades, its mission to coordinate all stages of the production process. ${ }^{162}$ Interbrigade "peer pressure," horizontal surveillance, reduced the need for external discipline, since each brigade's take depended on the price that the whole "link" received for its final product. ${ }^{163}$ As the 1977 Soviet Constitution declared, as a matter of law, "A programme [sic] is being consistently implemented in the USSR to convert agricultural work into a variety of industrial work, to extend the network of educational, cultural, and medical institutions, and of trade, public catering, service and public utility facilities in rural localities . . .."164

Collectivization of landholding ${ }^{165}$ initiated a profound transformation. Villagers still, for the most part, occupied separate cottages cultivating small kitchen gardens for personal consumption as villagers had previously; but fields were radically transformed by agglomeration. ${ }^{166}$ Economies of scale, the introduction of industrial agriculture, mechanization, and vast application of fertilizers and pesticides became the rule. Long after lands were pooled, "collectivization" meant forging a modern industrial enterprise of

161. See Karl Eugen Wadekin, The Private Sector in Soviet Agriculture (2d ed. 1973), cited in Kharkhordin, Collective AND the Individual, supra note 154, at 281.

162. See George Breslauer, Khrushchev and Brezhnev as Leaders 88-101 (1982) Khrushchev attempted to increase agricultural production and modernize the countryside via state investments in agricultural machinery and mineral fertilizer production. Id. at 92, 96. Simultaneously, he concentrated on rationalizing the organization of labor, intensifying pressure on local cadres, and initiating "anti-parasite" campaigns to boost production. Id. at $88,89,94$. Efforts to modernize and increase socialist agricultural production between 1961-1964 culminate in his support for a program of decentralization of managerial initiative combined with increased accountability for worker productivity, the "link" (zvenevaya) system. Id. at 101.

163. For description of "links" and further literature on them, see GEORGE BrESLAuer, Khrushchev and Brezhnev as Leaders 101-04 (1982). See also Kharkhordin, supra note 154, at 281-82 (describing the "link" system in the context of building collective subjectivity).

164. KONST. SSSR art. 22.

165. See infra Section II.A.2.a.

166. Agglomeration of many small parcels from individual farmers in a given area into one collectively held farm or state farm resulted, naturally, in larger parcels. Larger parcels are more suited to industrial farming, mechanization, and the applications of science, standardization, and specialization. See supra notes 150-162. 
farmers marked by specialization, division of labor, and the inculcation of mutual responsibility for the finished product. In short, legal doctrine created collective landholding and collectivizing landholding was an initial step towards creating a collectivized workforce. Oleg Kharkhordin refers to this new entity by its transliteration from Russian, a "kollektiv," collective both in material organization of life and in consciousness. ${ }^{167}$

\section{Community and Kollektiv}

Conventional Western property doctrine embeds the idea of community in collective ownership. ${ }^{168}$ There are political implications, even when a group is not specified as a political community; communal ownership involves policing ontological boundaries, determining insider and outsider status through the idiom of use or control: "Communal ownership means that the community denies to the state or to individual citizens the right to interfere with any person's exercise of community-owned rights."169 Dagan and Heller make community implicit in distinguishing a commons from an open-access resource, ${ }^{170}$ a commons being specifically "owned or controlled by a finite number of people who manage the resource together and exclude outsiders." 171 The state or collective farm of the Ukrainian countryside was, in this respect, a commons. While post-socialist land privatization targets collectivelyheld land, community is its collateral object.

To designate the user community of the sovkhoz of the kolkhoz, Kharkhordin's term kollektiv serves well. ${ }^{172}$ A kollektiv is meant to be a form of organization of experience with a particular material basis, set up for the purpose of cultivating a certain forms of sociability, identity, and personhood. ${ }^{173}$ Referencing the insights of Soviet Ukrainian educator A.S. Makarenko, Kharkhordin observes, "if one forms a kollektiv, one also forms a specific individual; engendering kollektiv and lichnost' [personality] are two sides of the

167. Kharkhordin, Collective and the Individual, supra note 154, at 77.

168. See, e.g., Demsetz, Property Theory, supra note 121, at 354 ("Communal ownership" means "a right which can be exercised by all members of the community."). For a reconsideration of the concept of community, see Alexander \& Peñalver, Properties of Community, supra note 21.

169. Demsetz, Property Theory, supra note 121, at 354.

170. "Open access property" is a scheme of "universally distributed, all-encompassing privilege." Dagan and Heller, Liberal Commons, supra note 123, at 557.

171. Id. (thus defining a "commons") (emphasis added).

172. See Kharkhordin, Collective and the Individual, supra note 154, at 77. See infra Section II.A.2.b.

173. See Kharkhordin, Collective and the Individual, supra note 154, at 77. 
same coin." 174 The central figure emerging from the Ukrainian socialist account is not, as was the case with each of the Western accounts, an individual, it is the Kollektiv-as long as we bear in mind that forming a kollektiv is not meant to obliterate the individual but rather is meant to engender a certain kind of individual. A question to bear in mind when considering post-Soviet decollectivization, then, is what would happen to this kind of community, a way of life and experience of the self, when its material basis was radically altered?

\section{B. Commons Meets Collective: Critiquing Collective Ownership}

\section{Collective Property, Collective Action}

During the same period that Ukrainians were constructing the rural collectives of late socialism, collective property appeared as a problem in Western scholarship. This Subsection is devoted to understanding how collective property is formulated as a problem in Western scholarship because this formulation occupies a central place in Western critique of Soviet socialism and thus becomes a primary justification for advocating post-Soviet privatization.

This line of scholarship proposes that collective ownership creates conditions for a particular kind of problem, a "collective action problem." It especially plagues groups holding collective property because rational, self-interested individuals will not necessarily form a group that acts rationally in the group's interests. ${ }^{175}$ If a member of a group can gain access to a benefit without exerting him or herself (that is, if a resource is "non-excludable" and therefore a public good), ${ }^{176}$ collective action to achieve the common benefit is imperiled. ${ }^{177}$

Hence, one form of property, the commons, ${ }^{178}$ is characterized as a breeding ground for collective action problems, particularly susceptible to free-riders and other abusers and thus particularly challenging to cooperation. Most famously, biologist Garrett Hardin argues that commons are structurally tragically prone to indviduals' overharvesting assets or overdumping liabilities. ${ }^{179}$ Eli-

174. Id.

175. See Mancur Olson, The Logic of Collective Action: Public Goods and the TheOry of Groups (1965).

176. Id. at $14-15$.

177. Id. at 2.

178. See, e.g., Ellickson, Property in Land, supra note 122, at 1322.

179. See Garrett Hardin, The Tragedy of the Commons, 162 SCI. 1243 (1968) [hereinafter Hardin, Tragedy of the Commons]; see also, e.g., D.W. Ehrenfield, Conserving Life on Earth (1972); Garrett Hardin, Political Requirements for Preserving our Common Heritage, in WILDLIFE 
nor Ostrom offers a more nuanced study, ${ }^{180}$ wherein the commonpool resource evokes solutions ranging from central government ownership (and management), to local management, to private ownership. ${ }^{181}$ Despite her contributions, however, the conventional remedy for the paradigmatic tragedy of the commons continues to dominate the discourse: the way to internalize externalities $^{182}$ and achieve proper allocation of cost and benefit is parceling the commons (or, in the case of an open-access resource, access to it). ${ }^{183}$

\section{Great Expectations: Two Tragedies of the Collective, Remedied?}

Western critique of Soviet collective property drew formative assumptions and understandings from Western understanding of the commons. As it famously alleged and disputed of the commons, it proposes the rural collective of the U.S.S.R. was structurally vulnerable to over-harvest of assets or over-dumping of liabilities, like Hardin's iconic commons. ${ }^{184}$ Despite empirical work on alternative approaches ${ }^{185}$ and synthetic work abstracting

AND AMERICA 310-17 (H.P. Brokaw ed., 1978); Ian Carruthers \& Roy Stoner, Economic Aspects and Policy Issues in Groundwater Development (World Bank, Staff Working Paper No. 496, 1981).

180. For a brief overview of three approaches to addressing collective action problems, see Elinor Ostrom, Governing the Commons: the Evolution of Institutions for ColLective Action 8-21 (1990) [hereinafter Ostrom, Governing the Commons].

181. Regarding private ownership in particular, see Demsetz, Property Theory, supra note 121, at 347-59; see also Ostrom, Governing the Commons, supra note 180, at 12-13 (discussing "Privatization as the 'only' Way"). While, Ostrom points out, it may at times be "difficult to know what analysts mean" when they refer to developing private rights to some common-pool resources, it is "clear that when they refer to land, they mean to divide the land into separate parcels and assign individual rights to hold, use, and transfer these parcels ...." Id. at 13 .

182. See Demsetz, Property Theory, supra note 121.

183. See id.; Hardin, Tragedy of the Commons, supra note 179, at 1245; see also James E. Krier, Marketlike Approaches: Their Past, Present, and Future, in Reforming Social Regulation: Alternative Public Policy Strategies 151 (LeRoy Gramer and Frederick Thomson eds. 1982). The conclusion about the tragic fate of open-access property is by no means universally shared. Some theorists suggest open-access property be seen not as tragedy but as comedy, i.e., not as the source of collective-action problems but as a source of solutions to them. See, e.g., Carol Rose, The Comedy of the Commons: Custom, Commerce, and Inherently Public Property, 53 U. ChI. L. Rev. 711 (1986).

184. See, e.g., Hardin, Tragedy of the Commons, supra note 179.

185. For a few examples of empirical scholarship on informal normative regimes regulating open-access and regulated-access property within a mixed regime of informal and formal normative orders, see, e.g., James M. Acheson, The Lobster Gangs of Maine (1988); Virginia Bernhard, Bermuda and Virginia in the Seventeenth Century: A Comparative View, 19 J. Soc. Hist. 57 (1985); D. Bruce Johnsen, The Formation and Protection of Property 
from them ${ }^{186}$, to deal with the "problem" of collective property, advice coalesced around privatization. ${ }^{187}$ This does not necessarily contradict the claim that the many bureaucratic controls on use of real property in the former U.S.S.R. created an "anti-commons" of rights that must be reassembled under unified ownership ${ }^{188}$ for efficient development. ${ }^{189}$ It may simply suggest a preferred sequence, reassembling managerial rights before a resource is converted to private ownership. Some suggest that land privatization captures previously wasted wealth, providing access to capital through the establishment of collateral ${ }^{190}$ and correctly aligning producer incentives to maximize efficiency. ${ }^{191}$ A few even propose that private property and a market economy are necessary conditions for democracy. ${ }^{192}$

This last argument points to a second line of critique. In addition to the generic paradigm of commons tragedy, a second, political, tragedy identified with state socialism lurked in Western consciousness: that collective ownership underwrote concentrations of political power resulting in authoritarianism. Here, tragedy takes the form of abuse of power and productive resources that come from consolidation and an absence of accounting. Collectivization in its destructive phase is cited; the famine in Ukraine is damning. Some historians indict collective property ownership in

Rights among the Southern Kwakiutl Indians, 15 J. Legal Stud. 41 (1986); Edmund S. Morgan, The Labor Problem at Jamestown 1607-18, 76 Aм. Hist. Rev. 595 (1971).

186. See W. Ophuls, Leviathan or Oblivion, in Toward a STEAdy State Economy 215-30 (H.E. Daly ed., Freeman 1973), summarized in Ostrom, Governing the Commons, supra note 180, at 8-11 ("Leviathan as the only way"); see also, e.g., Acheson, supra note 185; Robert Ellickson, Of Coase and Cattle: Dispute Resolution among Neighbors in Shasta County, 38 Stan. L. Rev. 623 (1985-86). For discussion and synthesis of several case studies, see Ostrom, Governing the Commons, supra note 180, at 18-19, 58-102, 143-81.

187. While a review of economic — rather than legal — accounts is beyond the scope of this Article, economists obviously participated actively as Western advisers to post-socialist governments, influenced governmental decision-making, and deserve mention. For an early participant, see, e.g., Jeffrey Sachs, Privatization in Eastern Europe: The Case of Poland, paper presented at the World Bank Annual Conference on Development Economics (Apr. 25-26, 1991), in Proceedings of the World Bank Annual Conference on Development Economics, 1991 (National Technical Information Office, 1992), cited in Cohen \& Schwartz, Privatization in Eastern Europe, supra note 12, at 10.

188. In Anglo-American legal parlance, what is called for is fee-simple ownership.

189. See, e.g., Heller, Anti-Commons, supra note 13, at 622-27.

190. See, e.g., Hernando de Soto, The Other Path: the Invisible Revolution in the THIRD WORLD (1989).

191. See, e.g., Andrei Schliefer, State Versus Private Ownership, 12 J. of Econ. Persp. 133 (1998) (private ownership yields greater efficiencies in production than state ownership because competition exerts pressure on private owners to innovate).

192. See, e.g., Janos Kornai, What the Change of System from Socialism to Capitalism Does and Does Not Mean, 14 J. of Econ. Persp. 27, 29, 35 (2000). 
providing the material support for an authoritarian from which Ukraine suffered disproportionately. ${ }^{193}$ The remedy for this tragedy is dispersal of assets to myriad private owners, thereby strengthening their democratic voice and bringing accountability and transparency to bear on state officials. ${ }^{194}$ This conception of the tragedy of the collective reflects familiar elements: a Libertarian concern with authoritarianism, a liberal concern with waste, a Jeffersonian answer of smallholding property owners.

This commons scholarship yielded conclusions about a two-fold tragedy of the Soviet collective. The tragedy of the collective lies in either waste to which private property brings efficiency; or authoritarianism, to which private property brings democracy. In either case, in this scholarship, the commons is the site of tragedy and private property, remedy.

\section{Property in Ideology: Market Democracy}

Several accounts of private property's beneficial relationship with a citizenry's capacity for self-governance, already in circulation in the West at the time of the dissolution of the U.S.S.R. ${ }^{195}$, combined with a diagnosis of economic and political tragedy of the Soviet collective for which privatization was the remedy. ${ }^{196}$ Liberty of Persons, Wealth of Nations, Democracy of Nations, and remedying economic and political tragedy of the Soviet collective are all staked to private property. Thus, from a diverse range of scholarly perspectives, private property emerges as the one remedy for sev-

193. See, e.g., Robert Conquest, The Harvest of Sorrow: Soviet Collectivization and the Terror-Famine (1986); Robert C. Tucker, Stalin in Power (1990); For Ellickson's brief discussion of the tragic effects of collectivization on Ukraine, see Ellickson, Property in Land, supra note 122 and accompanying text.

194. Transparency and accountability became watchwords of the age. For some, they refer to practices and values implicit in "neoliberalism," when it is taken to refer narrowly to specific traditions of ideas translated into techniques of contemporary government, such as governmental practices internally regulated by hard budget constraints. See, e.g., STEphen Collier, Post-Soviet Social: Neoliberalism, Social Modernity, Biopolitics (2011).

195. See infra Section I.A., I.B., and I.C. (discussing several paradigmatic accounts of the relationship between property and political community in U.S. legal scholarship).

196. Before the Soviet government dissolved the Union, some U.S. experts advocated less categorical change, urging government ownership, private lease-holding users, and local government management of leaseholds. See Nicolaus Tideman, Open Letter to Mikhail Gorbachev (Nov. 7, 1990) (letter from U.S. economics and law professors advocating Soviet Union not privatize land but instead have local governments determine and collect annual rents from users), cited in Michael A. Heller, View from the Trenches, supra note 13, at 204 n.4. After the dissolution of the U.S.S.R., such creativity largely evaporated and consensus in favor of wholesale privatization emerged. 
eral ills. ${ }^{197}$ An exemplary expression of this amalgam comes in Cass Sunstein's 1993 article, On Property and Constitutionalism. Written specifically in response to the dissolution of the U.S.S.R. and post-socialist transition, Sunstein urges the new post-socialist states to create private ownership rights in property, arguing that private property brings both prosperity and democracy, and that they in turn are mutually reinforcing. ${ }^{198}$

In the United States, accounts of the relationship between property and political community had given rise to beliefs, practices, blind spots, working assumptions: as under socialism, property had become a matter of ideology as well as theory. ${ }^{199}$ This includes an ideology of identity with property at its center, a defining diacritic of Cold War rivals. As Harvard professor of government Samuel Huntington expresses it, the United States' "national identity" is "defined by a set of universal political and economic values": "liberty, democracy, equality, private property, and markets." 200 Theory and ideology thus unite to provide questions and answers regarding the emergent situation.201 The United States and other Western governments circulated a new term, "market democ-

197. Their chorus drowns out a few prominent voices raised in skepticism, arguments neglected in policy formation and legal advising towards the former socialist states. For the latter, see, e.g., Alexander, A Fourth Way, supra note 10; Duncan Kennedy, Neither the Market nor the State: Housing Privatization Issues, in A Fourth Way?: Privatization, Property, And the Emergence of New Market Economics 253 (Gregory S. Alexander \& Grazyna Skápka, eds., 1994).

198. Sunstein, supra note 13; see also, e.g., Lake, Containment to Enlargement, supra note 9 (stating "America's core values:" "We see individuals as equally created with a Godgiven right to life, liberty and the pursuit of happiness. So we trust in the equal wisdom of free individuals to protect those rights: through democracy, as the process for best meeting shared needs in the face of competing desires; and through markets as the process for best meeting private needs in a way that expands opportunity.").

199. Cohen \& Schwartz, Privatization in Eastern Europe, supra note 12, at 8 (describing creation of private property as advised by American economists in post-socialist Europe as "one failed [. . .] ideology" replacing another).

200. Samuel Huntington, Why International Primacy Matters, 17:4 Int'L Security 68, 82 (1993); see also, e.g., Lake, Containment to Enlargement, supra note 9 (singling out democracy and market economics as "America's core concepts").

201. The sense of inevitability, the appearance of consensus, the absence of active policy debate over alternatives to land privatization are all features of an ideological milieu that had taken considerable time and energy to forge in the U.S. While beyond the scope of this Article, understanding the two decades of contention in the U.S. legal academy and in U.S. politics after the 1960s is critical to understanding how the appearance of consensus arose in regard to privatization after 1991. For one introduction to this background, see Duncan Kennedy, Three Globalizations of Law and Legal Thought: 1850-2000, in THE New Law and Economic Development: A Critical Appraisal 19 (David Trubek \& Alvaro Santos, eds., 2006). 
racy," 202 to express a link between economic and political liberalism that had become hegemonic.

Ideology of identity and ideas about security spurred policy. The U.S. government deemed transformation of the former Soviet states of "vital and historical importance" to the national security of the United States. ${ }^{203}$ Although "democratization" was the goal, property regime change was understood as inseparable from political regime change. In the transition to post-Soviet democratic governance, ran United States policy logic, "[I]f you do not privatize ... the whole thing is not going to work." 204 Promoting "market democracy" became a matter of national security. ${ }^{205}$ Privatization, its key reform, took on an air of inevitability. ${ }^{206}$

The Wealth of Nations account eclipsed alternatives and Western advising on economic and political reform hewed most closely to free-trade liberal policies. That said, in its ideals, Western engagement with post-Soviet reforms was informed by all three accounts. Even critics of Western economic advising in the postsocialist world like Janine Wedel 207 are invested; disappointed hopes like hers are the hopes of the three accounts. Programmatic aspects of liberalism and the hopes and ideals of others became subsumed under the heading of Market Democracy. ${ }^{208}$ This is not to say that this formed a coherent program, nor that contradictions between the various accounts had been reconciled. To the con-

202. Lake, Containment to Enlargement, supra note 9.

203. See U.S. Assistance to the Newly Independent States of the Former Soviet Union: Hearing Before the H. Comm. on Int'l Relations, 105th Cong. 10, 29 (1997) (statement of Thomas Dine, Assistant Administrator for Europe and the Newly Independent States, U.S. Agency for International Development).

204. See, e.g., U.S. Assistance to the Newly Independent States of the Former Soviet Union: Hearing Before the H. Comm. on Int'l Relations, 105th Cong. 10, 18 (1997) (statement of Ambassador Richard Morningstar, Special Advisor to the President and Secretary of State on Assistance to the Newly Independent States).

205. Lake, Containment to Enlargement, supra note 9 ("The successor to a doctrine of containment must be a strategy of enlargement - enlargement of the world's free community of market democracies."), excerpted in Anthony Lake, A Call to Enlarge Democracy's Reach, N.Y. Times (Sept. 26, 1993), available at http://www.nytimes.com/1993/09/26/week inreview/the-world-verbatim-a-call-to-enlarge-democracy-s-reach.html?scp=1\&sq=anthony+ lake\&sst=nyt (announcing a new national security doctrine for the United States in the postCold War period).

206. See, e.g., U.S. Assistance to the Newly Independent States of the Former Soviet Union, supra note 203; see also, e.g., John Williamson, Did the Washington Consensus Fail?, speech at Center for Strategic and International Studies, Washington, D.C. (Nov. 6, 2002) (transcript available at http://www.iie.com/publications/papers/paper.cfm?ResearchID=488) (characterizing the "Washington Consensus" agenda, including privatization and property rights, as "motherhood and apple pie, which is why they command a consensus").

207. See Wedel, Collision and Collusion, supra note 8.

208. See Sunstein, supra note 13. 
trary. Some of these internal contradictions arose in the course of law-reform advising schemes, a set of engagements that have yet to be fully studied. But in their ideals, all three promised prosperity, or at least economic self-sufficiency, and an economic basis favorable to democracy. It was in their ends-prosperity and democracy-and in their common starting point-private property-that they found common ground. Connecting the starting point with the ends was where they differed and was opened up to the least examination at the time privatization advice was promulgated.

The post-Soviet Ukrainian government paid heed to pro-privatization Western scholarship and advocacy, deciding to unravel collective ownership, parcel, and privatize in pursuit of economic and political reform. During the decade of debates over legalizing private property in the Ukrainian parliament, those in favor as well as those opposed expected private property ownership to unleash self-interest. ${ }^{209}$ Both sides expected a change in the soon-to-be property owners, either more responsible, punctual, and less prone to alcoholism, for example, or more greedy, self-serving, or exploitative.

The response in the countryside was dramatic but startling to all. In the period during which they received their plots of land, close to $60 \%$ of the rural population evacuated their homes and moved to a city within Ukraine. ${ }^{210}$ This came in addition to five million, or $10 \%$ of the population, that had left Ukraine since independence in 1991.211 Not all farmlands were abandoned, of course. A few farms operating today exceed expectations, dazzling in their capital investment and productivity. ${ }^{212}$ Most, however, are dismay-

209. See, e.g., Ukrainian Communist Lawmakers Protest for Second Day Against Land Code, Kyrv Post (Oct. 26, 2001), available at http://www.kyivpost.com/content/ukraine/ukrain ian-communist-lawmakers-protest-for-second-d-9976.html.

210. See International Organization for Migration Kyiv Mission, Labour Migration Assessment for the WNIS Region (Oct. 2007) [hereinafter IOM Labour Migration Assessment].

211. Roughly two million emigrated permanently. Another 3 million left as labor migrants, intending to return to Ukraine. See The State and Problems of Legal and Social Status of Contemporary Ukrainian Labor Migration, Hearing of Parliament of Ukraine (Nov. 17, 2004) [hereinafter Labor Migration Hearing], available at http//portal.rada.gov.ua. Other research indicates the figure for temporary labor migration might be higher. In April 2006, $15.7 \%$ of households reported at least one person had temporary work outside Ukraine, according to the Institute of Sociology of the National Academy of Sciences of Ukraine. See Institute of Sociology of the National Academy of Sciences of Ukraine, Ukrainian Society 1992-2006 (V.Vorona, M.Shulga eds., 2006), cited in IOM Labour Migration Assessment, supra note 210.

212. See infra Section III. 
ingly deserted, abandoned by their working-age owners, populated mostly by the very old with a small portion of the very young. ${ }^{213}$ The next two Sections examine the emergence of these settings, boomtown and ghost town, in more detail.

\section{Boomtown}

This Section summarizes implementation of land privatization in Ukraine in one locale. ${ }^{214}$ On the ground in Ukraine, building a "market democracy" was not uppermost in the minds of Ukrainian pioneers of privatization. This section describes some of their motivations, constraints, and actions within a legal background.

Enterprise privatization predated land privatization in Ukraine. ${ }^{215}$ Even before land privatization decollectivized farms, the state had privatized facilities for food transport and food processing-grain elevators, mills-upon which farms depend to get their produce to consumers. ${ }^{216}$ The village of Yashkiv is home to a sugar-beet sugar factory upon which farmers of the surrounding countryside depend to process the most valuable of their crops. This is the story of how the Sugar Beet Factory of Yashkiv (although privatized to its workers through enterprise privatization) and the land of the surrounding collective farms (although privatized to their farmers through land privatization) have ended up under the de facto control of a group implicated in organized crime. ${ }^{217}$ Though only one slice of a diverse range of experience, it illuminates how implementation of land privatization may allow most of

213. See infra Section IV.

214. The ethnographic material in Section III is summarized from Monica Eppinger, Reforming the Nation: Law and Land in Post-Soviet Ukraine 64-79 (2010) [hereinafter Eppinger, Law and Land III] (unpublished Ph.D. dissertation, University of California Berkeley) (on file with the University of California Berkeley Library).

215. See "On Privatization of Property of State-Owned Enterprises," Resolution of Parliament of Ukr. No. 2164-12 (Mar. 4, 1992), amended by laws No. 2544-12 (July 7, 1992), No. 2621-12 (Mar. 18, 1992), No. 3875-12 (Jan. 26, 1994), No. 3982-12 (Feb. 22, 1994), and No. 64/95 (Feb. 15, 1995), and by Decrees of the Cabinet of Ministers No. 9-92 (Jan. 21, 1993) and No. 15-93 (Feb. 19, 1993), available at http://www.brama.com/law/privatization/ privat_e.txt. For description of the creation of a legal basis for enterprise privatization and the progress and setbacks of implementing enterprise privatization, see Yuri I. Yekhanurov, The Progress of Privatization, in Economic Reform in Ukraine: The Unfinished Agenda, 189-206 (Anders Aslund \& George DeMenil eds., 2000).

216. See, e.g., USAID, taSk ORdER NO. OUt-EPE-I-804-95-00079-00, Ukraine Agro-Monopolies Privatization Project (1999), available at http://pdf.usaid.gov/pdf_docs/Pdabr 927.pdf (progress report on Ukrainian grain elevators and other storage facilities from 1999, two years before the land privatization law passed).

217. See infra Section III.C. (describing these groups, or "clans" (Ukrainian and Russian: klani), in greater detail). 
the rural land assets of value to end up in the hands of few and how that in turn will affect political community in Ukraine.

\section{A. The Factory: Integration, Circulation, Concentration}

The Yashkiv factory is a point of articulation between national structures and the local countryside. First, as an asset of the Ukrainian Foodstuffs Company (UFC), a national food processing division of the multi-sector holding company Brovarych, it connects the locale to supralocal economic structures. UFC and four rival companies own $40 \%$ of the sugar factories in Ukraine, the remaining $60 \%$ either so run-down or lacking in beet supplies that the five competitors control $70 \%$ of the domestic sugar market. ${ }^{218}$

The conceptualization of sugar beet processing puts the factory in a particular relationship with the local countryside as well. Investors reckon a sugar beet factory's potential profitability by its "zona", an organizing principle of Soviet agronomy relating to the local farms that supply a factory with beets. ${ }^{219}$ (Yashkiv's zona comprises two former collective farms in surrounding areas, totaling 70,500 hectares, equivalent to 272 square miles.) When UFC started investing in sugar beet factories nationally in 1995, they found the beet supply unreliable.220 Farms' equipment was old ("and it was not that great to start with") ${ }^{221}$ and liquidity or credit to purchase newer technology or inputs like seeds, fertilizer, or herbicide was unavailable. ${ }^{222}$ UFC dispensed with buying beets and turned to producing beets themselves, leasing the farmlands of the zona together with landowner labor, ${ }^{223}$ deals negotiated in aggregate with the collective farm director who negotiated on behalf of the collective. ${ }^{224}$ These leaseholds became increasingly acceptable

218. See Interview with Mikhail Leonidovich Goldenberg, Founding Partner, Ukr. Foodstuffs Co. (June 17, 2002), cited in Eppinger, Law and Land III, supra note 214, at 64.

219. See Eppinger, Law and Land III, supra note 214, at 67.

220. See id. at 66.

221. Interview with Mikhail Leonidovich Goldenberg, supra note 218, at 64 .

222. See id. The kholkhoznik [collective farmer] has no realistic access to credit, according to a UFC investor: Even with a now-privatized land parcel, "they're fourth out of four classes of creditors banks consider. No money in the bank, no history with the bank, and if they don't pay you back the most you can get is a plot of land that even the local farmer couldn't make work." Id. at 64 n.174.

223. Verdery coins the term "super-renter" to describe such a land user in privatized Romania, higher in social and financial hierarchies than the landlord from whom he rents. Katherine Verdery, The Vanishing Hectare: Property and Value in Postsocialist Transylvania 310-338 (2003) [hereinafter Verdery, Vanishing Hectare]. On "super-renters", see id. at 322 .

224. See Eppinger, Law and Land III, supra note 214, at 65. At the time of the leasehold negotiations, before the land privatization law, collective farmers had received share certifi- 
as collateral in private capital markets the more likely it seemed land privatization would make it into legislation. ${ }^{225}$ Borrowing in anticipation of the land privatization law's passage in October 2001, UFC spent more than \$3 million between August 2001 and March 2002 on capital equipment for its farming operations in the Yashkiw zona. ${ }^{226}$ While it spends big on equipment for lands it does not own, UFC is chary with the sugar factory, which it does own. ${ }^{227}$ The sugar factory has thus, under the UFC owners, become a point of articulation between the international and the local at which circulations of international capital and equipment funnel down and local labor and beets are concentrated in sugar and funnel up.

Raising sugar beets requires crop rotation, so UFC's rented fields regularly produce wheat or corn instead of beets.228 Accordingly, UFC owns a controlling packet of shares in the Yashkiv grain elevator, a separate operation from the sugar-beet factory. ${ }^{229}$ In fact, UFC owns substantially all of the other functioning enterprises in Yashkiv, privatized in the 1990s and mostly related to food processing. ${ }^{230}$ UFC donations keep the local schools running as well, providing heat through the winter and computers for classrooms. ${ }^{231}$ The level of care of company toward local residents influences corporate land ownership decisions. ${ }^{232}$ Overall, the extent of horizontal integration between UFC, the town, and the zona is striking.

cates but not plots. See infra Section IV.A. (explaining share certificate allotment, plot demarcation, and parcelization).

225. Eppinger, Law and Land III, supra note 214. For anthropological treatment of the concept and practice of collateral, see generally Annelise Riles, Collateral Knowledge: Legal Reasoning in the Global Financial Markets (2011).

226. See id. at 68.

227. See Interview with Mikhail Leonidovich Goldenberg, supra note 218, at 66.

228. Eppinger, Law and Land III, supra note 214, at 70.

229. See Interview with Mikhail Leonidovich Goldenberg, supra note 218, at 64 .

230. See id.

231. See Interview with Valentyn Sergeyevich, Dir. Yashkiv Sugar Beet Factory (June 17, 2002), cited in Eppinger, Law and Land III, supra note 214, at 67. When asked why the sugar factory shouldered a substantial amount of the expenses of the local K-12 schools when asked for help, he answered, "How can you say no? That's our school. Our kids go there [meaning, his workers' kids]. We don't do everything, but we do what we can." Id.

232. See Eppinger, Law and Land III, supra note 214, at 66. Explaining why the company would prefer to lease land instead of buy, Sergei Aleksandrovich Pokushai, Exec. Dir., Ukr. Foodstuffs Co., stated, "It's way too expensive. You buy enough land to farm with 40 or 50 people; 200 people live there, and you have to take care of all of them: health care, schools, the whole range of social services." See Interview with Sergei Aleksandrovich Pokushai, Exec. Dir., Ukr. Foodstuffs Co. (June 14, 2002), in Eppinger, Law and Land III, supra note 214, at 66 . Although the obligation to provide social services is not required by law, it is keenly felt nonetheless: "No, the obligation does not come from the law. But for 70 years [of Soviet life], we lived like that - people expected if you give them work, you give 


\section{B. Origins of Corporation: Social and Financial Capital}

At the time of UFC's inception in 1995, just three founders and a secretary under the Brovarych umbrella, Brovarych was already a major player in the Ukrainian economy.233 Among other activities, from the early 1990s Brovarych had been one of the main energy traders in Ukraine. ${ }^{234}$ Squeezed out of the barter market for oil products by rougher Russian competitors in the mid-1990s, Brovarych began looking for activities. ${ }^{235}$ Its diesel trade had brought it into regular contact with sugar factories. "We were used to dealing with them, we had relationships with them."236 The four employees of UFC and Brovarych, looking for niches into which other private companies had not ventured, decided to try sugar. ${ }^{237}$

None of the four had prior experience in agriculture or food processing, but that was not as important as their relationships with sugar-factory directors and with Brovarych head Hrihoriy Medved, who had access to funds. Medved provided the start-up capital for buying factories, but UFC had to make its debt payments to Medved and turn a profit from the first year. ${ }^{238}$ (To purchase combines for the Yashkiv zona, UFC could obtain loans from an Austrian investment bank, and at a much better interest rate, thanks to the 2001 changes to the land law changing perceptions and creating collateral value in leaseholds.) ${ }^{239}$

The results in Yashkiv have been remarkably profitable and socially constructive. In the first two years after UFC acquired it and began providing inputs and equipment to farmers in the zona, sugar output at the factory more than doubled. ${ }^{240}$ For the 15,865 residents of Yashkiv ${ }^{241}$ and the farmers of the zona, the advent of UFC's investment has meant steady paychecks for the first time since the Soviet Union dissolved. ${ }^{242}$ The overall picture is one of a

them social services. What are you going to do? Suddenly throw them out on the streets?" Id.

233. See Eppinger, Law and Land III, supra note 214, at 70.

234. See id.

235. See id.

236. Interview with Mikhail Leonidovich Goldenberg, supra note 218, at 70.

237. See id.

238. See Eppinger, Law and Land III, supra note 214, at 71.

239. See id. at 69.

240. From 54 tons in the year 1 harvest to 130 tons in the year 3 harvest. See Eppinger, Law and Land III, supra note 214, at 69.

241. Population figure as of 2001 from the Association of Ukrainian Cities, www.auc.org.ua.

242. See Interview with Misha Kukel, Driver for Zhashkiv Sugar-Beet Sugar Factory (June 17, 2002), cited in Eppinger, Law and Land III, supra note 214, at 69. 
reversal of an inefficient drain of local resources: an agriculture drain, as beets and other local crops were grown and processed less efficiently; a combine-drain, as existing farm equipment, in the absence of reinvestment, was cannibalized for parts; a brain-drain, as the most talented, ambitious, or hungry of the area outmigrated. ${ }^{243}$ The situation in Yashkiv has turned around thanks to UFC's investment. UFC, in turn, praises the Land Code as the most important development that has aided its enterprises. ${ }^{244}$

\section{Acquisition}

The story of successful economic development through land privatization is not that simple, however, for two complicating reasons. The first is the means by which UFC acquired the Yashkiv factory and its other plants. The second is the place of parent company Brovarych, and its owner, Medved, in the social structure of Ukrainian politics during this period in which the political elite undertook fundamental reforms through legal change.

Changes in tax law set the stage for UFC's maneuvering. Tax legislation in the mid-1990s on collective farms lacked clarity because of the changing, and thus unclear, status of legal ownership of collective farm land. For example, the 1996 law setting land tax rates reads, "Tax means monetary payment by legal entities and private individuals for the use of land parcels."245 The reformers in parliament could read it as a property tax on privatelyheld land; their antagonists could read it as national rental rates for use of state-owned land. ${ }^{246}$ The land tax law set an annual .1\% tax on the value of a land parcel (determined per land-value formulas set during the Nazi occupation of Ukraine) ${ }^{247}$ Land taxes were thus instituted when the state still controlled prices of most grain and commodity prices did not keep pace with rising tax costs

243. The principal of a local school beamed with pride as he spoke of the factory director UFC hired in Kyiv to run the Yashkiv factory. "He's a Yashkiv boy. He's the first one in fifteen years who left the town to attend university or work, and came back to us. We need more like him." (The factory director returned to Yashkiv in October 2000 as an employee of UFC/Brovarych.) Interview with Ivan Ivanovych, Principal, Yashkiv Cent. Sch. (June 17, 2002), cited in Eppinger, Law and Land III, supra note 214, at 69.

244. See Goldenberg, supra note 218.

245. The Law of Ukraine amending the Law of Ukraine "On Payment for Land," art. 1, No. 378/96, Sept. 19, 1996, and No. 379/96 Jan. 1, 1997, with amendments introduced by The Law of Ukraine, No. 404/97, July 27, 1997.

246. Lest it be confused with an income tax on the fruits of agricultural land, the law specifies, "The amount of land tax does not depend on the results of production activities of land owners and land users." Id. art. 4.

247. See id. 
to producers. ${ }^{248}$ Massive defaults on tax and tax-penalty debts by state enterprises followed. ${ }^{249}$

The Yashkiv sugar factory had been privatized and formally belonged to its worker-shareholders. ${ }^{250}$ It had also been subject to the national property tax for the first time since pre-Soviet times during a time when controlled commodity prices and a collapsing economy meant that revenues could not keep up with its property tax debt. ${ }^{251}$ The four employees of UFC made it their business to research the sugar-beet factories of Ukraine. ${ }^{252}$ Their research mainly covered two areas. First, they researched which factories had the largest profit potential based on longitudinal studies of Soviet-era production. ${ }^{253}$ Soviet agronomy taught that, while tinkering with plant equipment can reap marginal increases in efficiency, the largest determinant of productivity is the fertility of the land around a sugar-beet factory, the zona. ${ }^{254}$ UFC's first step was to locate sugar factories whose zona yielded a much higher ratio of sugar-per-beet than other factories'. ${ }^{255}$ This information rested largely in local and national archives not organized to facilitate public access. Finding the correct records depended on the expertise, and sometimes the permission to search, of archivists. ${ }^{256}$ The UFC employees secured archivists' cooperation partly through bribes and sometimes through the fear or respect inspired by Medved's reputation as head of the "Kiev Klan."257

A type of "financial-industrial group," this formation and its head, the oligarch, are figures that by the mid-1990s became a prominent feature of discussions of business organization across the former Soviet Union. Ukrainian analysts call the most powerful of these political and economic alliances klani (clans). ${ }^{258} \mathrm{Klani}$

248. See Eppinger, Law and Land III, supra note 214, at 72.

249. See Interview with Bohdan Chomiak, Officer of Agric. Land Programs, USAID Kyiv (June 20, 2002).

250. See Eppinger, Law and Land III, supra note 214, at 72.

251. See id.

252. See id.

253. Id. at 72-73.

254. Id. at 73 .

255. Id.

256. Id.

257. In order to distinguish this metaphor from the technical kinship term, I will refer to it by the transliteration of the Soviet word klan (pl. klani). There is no relation to the U.S. Ku Klux Klan, colloquially called "the Klan" in American English.

258. See, e.g., Slavko Pikhovshek, Dnipropetrovsk vs. the Security Service (1996) [hereinafter Pikhovshek, Dnipropetrovsk]. For a an analytical description of "clans" in another region of the post-Soviet space, see Edward Schatz, Modern Clan Politics: The Power of "Blood" in KazAkhstan and Beyond (2004). For an operational description of 
are not synonymous with the mafia. The latter, by definition, concentrate on running protection rackets parasitic on other businesses whereas the former run businesses themselves. Mafia activity thus by definition rivals the state's monopoly on the legitimate use of force and is thus categorically outside the law. ${ }^{259}$ The core of klan activity is, by and large, within the law. In fact, klani make it part of their business to support political parties and politicians and thereby to help make the law. ${ }^{260}$ However, klani, like the mafia, are creatures of post-socialist private property rights, although the relationships between core members may originate in the social networks of late socialism. ${ }^{261}$ The typical klan unites several forms of private property - a private bank or other institution specialized in arranging credit or formalizing informal financial arrangements; a powerful industrial enterprise or sector; media outlets - and several conduits to elected officials or state bureaucracies. In Ukraine, the networks of relationships ${ }^{262}$ along which klan sociability runs are often based in klan members' regions of origin in late socialism. ${ }^{263}$ The concept of klani illuminates one mode in which members of the political elite may take collective action on a given problem.

To return to UFC's entry into the sugar-beet sugar business, in addition to gathering soil-yield information, UFC manipulated the tax collection process to acquire the plant at a non-public auction. ${ }^{264}$ In order to do this, the three directors ascertained the tax debt owed by those factories whose zona promised the highest

\footnotetext{
"clans" in Russia after President Putin's re-election, see Minchenko Consulting, Vladimir Putin's Big Government and Politburo 2.0 (Oct. 3, 2012), available at http:// minchenko.ru/netcat_files/File/Big\%20Government $\% 20$ and $\% 20$ the $\% 20$ Politburo $\% 20$ 2_0.pdf; Minchenko Consulting, Politburo 2.0 Ahead of a Realignment of Elite Groups (Jan.-Feb. 2013), available at http://www.minchenko.ru/netcat_files/File/ MC\%20_report.doc; Laurnas Kasnas, Marius Laurnaviius, \& Vytautas Kersanskas, Vladimir Putin's Pyramid of Rule: Who Really Governs Russia?, Delfi: The Lithuanian Tribute (Aug. 4, 2014), available at http://en.delfi.lt/central-eastern-europe/vladimir-putins-pyramid-ofrule-who-really-governs-russia.d?id $=65432116$.

259. For a description of mafia, see, e.g., Frederico Varese, The Russian Mafia (2001).

260. See generally Eppinger, Law and Land III, supra note 214, at 74-79.

261. For description of how late Soviet social networks became active in the post-Soviet context in Russia, see, e.g., Alexei Yurchak, Entrepreneurial Governmentality in post-Socialist Russia: a Cultural Investigation of Business Practices, in The New Entrepreneurs of Europe AND AsIa (Victoria Bonnell \& Thomas Gold eds., 1999) [hereinafter Yurchak, Entrepreneurial Governmentality].

262. For discussion of Soviet networks, see Kharkhordin, Collective and the IndividUAL, supra note 154 , at $315-16$.

263. See Pikhovshek, Dnipropetrovsk, supra note 258.

264. See Eppinger, Law and Land III, supra note 214, at 73.
} 
profit potential. The law is silent on the privacy of tax records, but as a matter of practice, tax records are not publicly available in Ukraine. ${ }^{265}$ Finding out tax debt information meant cultivating contacts in the tax administration at the local government (raion) level and activating Brovarych contacts in Kiev. ${ }^{266}$ Armed with figures on tax arrears, UFC would draw the attention of the Tax Inspectorate in Kiev to the plant's tax debt. ${ }^{267}$ The Tax Inspectorate, responsible for inspecting and collecting on tax debts nationwide, is overwhelmed with enterprises in arrears. ${ }^{268}$ It has the reputation for choosing which enterprises to investigate based on executive-branch orders aimed at businesses of political rivals or takeover targets. ${ }^{269}$ The Tax Inspectorate, having the authority to seize real property or other assets to satisfy tax arrears, is often feared by enterprise directors and owners. ${ }^{270}$ Rather than a partial seizure of assets that could reduce a plant's productive capacity, UFC would propose an alternative solution: a quiet seizure of the plant by the tax authority and subsequent "auction" to a buyer willing and able to satisfy the tax debt. ${ }^{271}$ The tax authority would agree to this arrangement (and often, the plant director would be notified), and the entire seizure and resale would be effected in a single day, without public notice. ${ }^{272}$

This process accomplished three purposes. It allowed UFC to acquire plants that had already been privatized and which were not currently "for sale" (either because the worker-owners did not wish to sell, or because there was effectively no market for enterprises in Ukraine after the first generation of privatization had taken place). Second, it allowed UFC to acquire plants without attracting poten-

265. See generally Podatkovii Kodeks Ukraini, Vidomosti Verkhovnoi Radi Ukraini (VVR), (Tax Code of Ukraine, Bulletin of the Supreme Rada of Ukraine) 2011, No. 13-14, No. 15-16, No. 17, at 112, available at http://zakon4.rada.gov.ua/laws/show/en/2755-17.

266. See Eppinger, Law and Land III, supra note 214, at 73.

267. See id.

268. See id. For description of the Tax Inspectorate's duties, see generally website of the State Fiscal Service of Ukraine, available at http://sfs.gov.ua/. For comparative analysis of Ukraine's Tax Inspectorate, see Verena Fritz, State-Building: A Comparative Study of Ukraine, Lithuania, Belarus, and Russia (2007).

269. See, e.g., Taras Kuzio, Ukraine Moves to State Capitalism and "Militocracy," Eurasia DAILY Monitor (Dec. 2, 2011), available at http://www.jamestown.org/programs/edm/ single/?tx_ttnews\%5Btt_news\%5D=38740\&cHash=e2daaca2b0f009f27710104220fdd80f\#.

VRSSZChSark; see also, e.g., Criminal Case Opened Against Top Tax Official in Crimea, Kriv Post (MAY 4, 2011), available at http://www.kyivpost.com/content/ukraine/criminal-caseopened-against-top-tax-inspectorate-103619.html.

270. See Kuzio, supra note 288.

271. Eppinger, Law and Land III, supra note 214, at 73.

272. See id. at 71 . 
tial competitive bidders, for prices well below the market valuation (upon which, inter alia, the property tax had supposedly been based). Finally, it allowed UFC to acquire plants without attracting the attention or ire of Brovarych's political and economic rivals as participation in public auction might have done.

UFC found it prudent to keep a low profile because, among other reasons, Hrihoriy Medved is a klan leader whom some also consider heavily implicated in Ukrainian organized crime. ${ }^{273}$ Medved avoids attracting the attention of rivals or provoking the jealousy of allies. He raised his initial capital through various black market dealings in the late Soviet and early independence periods; UFC was one of the agricultural subsidiaries through which he laundered those profits after 1994. ${ }^{274}$ Medved provided three essential assets to the four employees of UFC. He supplied them with contacts at the tax inspectorate and elsewhere in order to learn what they needed about tax arrears and to make trustworthy deals on tax-arrear auctions. ${ }^{275}$ He supplied them with a fierce reputation, so that interlocutors at the local level or in Kiev would not cross them. ${ }^{276}$ Finally, he supplied them with start-up capital with which to purchase the tax debt for the first UFC plants and cover other initial costs. ${ }^{277}$ These three assets, I propose, were necessary for leveraging the anti-commons in Ukraine. Medved's reputation and networks, more than individual bribes, allowed UFC to obtain from public officials information not otherwise available and to use it in ways not available to other members of the public. His reputation raised the perceived costs to individual officials of not cooperating and raised confidence that they would be protected from subsequent sanction by their supervisors. ${ }^{278}$ Given that UFC exists by the grace of Brovarych, a political-economic alliance, it takes a great interest in local politics; given the extent of horizontal integration, few elections in Yashkiv or its zona take place outside of the network of relations and expectations of UFC's political affiliates.

273. For a report produced for interested Western readers on the overlap in social networks between post-Soviet entrepreneurs and organized crime in Ukraine at the time Medved was consolidating his Yashkiv holdings, see, e.g., Alexander N. Yarmysh, Ukrainian Organized Crime Groups: A Behavioral Model 10-13 (2004) (unpublished copy made available by National Criminal Justice Reference Service of U.S. Department of Justice at https://www.ncjrs.gov/pdffiles1/pr/204378.pdf).

274. See Eppinger, Law and Land III, supra note 214, at 74.

275. See id.

276. See id.

277. Id.

278. See id. at 66-79. 


\section{Review of the Boomtown}

The dramatic increase in agricultural production after land privatization in Yashkiv and its zona is typical of a nation-wide boom after the collective farms were disbanded.279 In this Section, I investigate how that happened. As the next Section describes, the land privatization law and previous executive orders provide a foundation for private investment in agriculture. ${ }^{280}$ The argument that I make in this Section is that the legal measures awarding title to agricultural land are not sufficient to explain who controls agricultural land or production. The efficiency gains from production on privately-owned agricultural land must pass through funnels to get to market: food storage, transport, and processing facilities. ${ }^{281}$ Second, while market incentives now shape the activities of investors in the agricultural sector, their behavior cannot be explained without reference to prior norms of responsibility and forms of care of plant managers (in this case, the UFC owners) to farmers and workers. ${ }^{282}$ Third, a small number of investors in the agricultural sector have amassed large amounts of land through leaseholds with newly privatized farmers. ${ }^{283}$ Typically these investors are corporations but, like the UFC investing in Yashkiv, consist of a very small number of persons: by $2004,16 \%$ of the corporate farms nationally were single-shareholder entities and $31 \%$ had from 1-3 shareholders. ${ }^{284}$ While the number of people in the investing corporation is small, the amount of privatized land they control is large, averaging in one authoritative survey 1700 hectares, which is three times larger than the average corporate farm in the U.S. (500-600 hectares). ${ }^{285}$ Fourth, banks are not making loans to the new rural landowners to purchase equipment.286 They are making loans to these cosmopolitan "brokers" who mediate provisions of capital between the Ukrainian countryside and international capital, obtaining loans in part based on the perceived collateral value of their leaseholds from the new private farmers. ${ }^{287}$

279. National agricultural productivity rose 30\% between 1999 and 2004. See, e.g., ZVI Lerman, et al., Ukraine after 2000: A Fundamental Change in Land and Farm Policy? 2 (2006) [hereinafter FAO Land Policy Report], available at http://departments.agri.huji. ac.il/economics/lerman-fao-study.pdf.

280. See infra Section IV.A.

281. See text infra Section III.A.

282. See text infra Section III.B.

283. See infra Section III.C.

284. See FAO Land Policy Report, supra note 279, at 2.

285. See id. at 3.

286. See Eppinger, Law and Land III, supra note 214, at 78.

287. See id. 
For some of these brokers, crime provided the initial capital and corruption shaped early patterns of legitimate investment in the agricultural sector, setting investment organizations that began as criminal groups on a trajectory of ownership and influence in the future. ${ }^{288}$ Establishing a market, and relying on market incentives alone, will not result in an optimally functioning economy or democracy. In fact, supplying organized criminal groups with fixed legal assets may put both the economy and the political system on trajectories for a distinctly worse future. The central figure of this property account is not the landowner but the Oligarch, by which we mean both the person at the apex of a financial-industrial group, the aspirants that would be head, and the supporting members of his klan.

The klani have not infiltrated most villages and former collective farm areas in Ukraine. The next Section describes these areas devoid of investors, far from access to international financial markets, left to their own devices. The boomtown enjoys dramatic gains in efficiency and agricultural production but potentially disastrous effects on democratic development. In the ghost town, we see practically its converse.

\section{Ghost Town}

The Boomtown is the exception; its counterpart of the rural countryside, the Ghost Town, is the rule. The following account situates creation of the ghost town within larger processes of building a post-Soviet state. ${ }^{289}$ The first part hinges on altering the basis of the right to exclude. In this "legislative history," the history of legal measures is interwoven with the history of creating the authority to enact legal measures. The evolution of property rights occurs in tandem with governance practices and formal institutions of political community. The second part of the ghost town story turns on the reintroduction of mobility to Ukrainian village life, part of a larger untethering process of decolonization. Together, these measures created the conditions of possibility for the ghost towns that haunt most of the Ukrainian countryside. This Section concludes with a brief description of life in the ghost town.

288. See id.

289. The ethnographic material in Section IV is summarized from Monica Eppinger, Reforming the Nation: Law and Land in Post-Soviet Ukraine, at 77-92, esp. 77-78 and 87-90 (2010) (unpublished Ph.D. dissertation, University of California Berkeley) (on file with the University of California Berkeley Library) [hereinafter Eppinger, Law and Land IV]. 


\section{A. Capital Games, Conversions, Divisions, and Untethering}

With independence, national policy decisions including land privatization were implicated in broader struggles over state formation and economic. Power was unsettled. ${ }^{290}$ In the five years before a post-Soviet constitution passed ${ }^{291}$, the President operated within a late-Soviet-shaped mantle of executive power, strong on bureaucratic centralization but short on nimbleness. ${ }^{292}$ The parliament, stilled called the Supreme Soviet (Verkhovna Rada), contained a mix: anti-Soviet Ukrainian nationalists; pro-reform pragmatists; and Socialists, Communists, and those resistant to change. ${ }^{293}$ Core among the latter, directors of collective farms elected to parliament from their village voting districts (nicknamed the "Red Directors") opposed pro-market reforms that might undermine their local authority. ${ }^{294}$ Land privatization and other economic reforms were debated at the same time, and by the same people, as constitutional divisions of power between the branches; federal questions of central versus local power; and rules for allocating the productive assets of the Soviet state that could determine personal enrichment. ${ }^{295}$ Among political actors in Kyiv, moves to break up or keep collective farms were part of a strategy in several simultaneous short-term and long-term games.

An initial step towards decollectivization came in two 1995 presidential orders. The first abolished state farms and converted them into collective farms (collectively but undividedly owned by the residents of the farm). ${ }^{296}$ The second provided that each resident

290. See Monica Eppinger, On Common Sense, in Studying Up, Down, and Sideways: Anthropology Aт WORK 194 (Rachael Stryker and Roberto Gonzalez eds., 2014) [hereinafter Eppinger, On Common Sense].

291. See Konst. Ukr. [Ukraine Constitution] (1996) [hereinafter Konst. Ukr.].

292. See Eppinger, On Common Sense, supra note 290, at 194-204.

293. See D. Nohlen and P. Stöver, Elections in Europe: A Data Handbook, 1961 (2010); see also Sarah Whitmore, State-Building in Ukraine: The Ukrainian Parliament, 1990-2003 49-91 (2004).

294. See Whitmore, supra note 293, chs 3-5.

295. For discussion of the allocations of state assets and other maneuvers during the formation of state power in post-Soviet Ukraine during the 1990s and early 2000s, see, e.g., Paul D'Anieri, Understanding Ukrainian Politics: Power, Politics, and Institutional DESIGN (2007) (evaluating multi-party state institution-building in light of power politics in Ukraine); see also, e.g., Serhiy Kudelia, Revolutionary Bargain: The Unmaking of Ukraine's Autocracy Through Pacting, in Democratic Revolution in Ukraine: From Kuchmagate to Orange Revolution 78-101 (Taras Kuzio ed., 2013).

296. See Ukaz Prezidenta Ukraini "Pro Poryadok Payuvannya Zemel, Peredannikh u Kollektivny Vlasnist Silskohospodarskim Pidpriemstvam i Organizatsiyam” [Order of the President of Ukraine "On the Parcelization of Land, Given into Collective Ownership to Agricultural Enterprises and Organizations"], Order No. 720/95, Aug. 8, 1995 [hereinafter Presidential Order No. 720/95 on Parcelization], reprinted in Zakonodavstvo Ukraini Pro 
or retired worker of a collective farm be issued a "land and asset certificate" documenting the person's ownership of a share of the farm. ${ }^{297}$ Every farm was to set up a "Land Committee" to compile a list of residents and pensioners who "belonged" to the farm and were therefore entitled to certificates. This order introduced farmers to the concept of divisibility and created an exercise by which farmers imagined division of the collective. However, as a practical matter it also reinforced some of the bonds within the collective, for example, by forcing local committees to name who belonged to the farm and who did not. ${ }^{298}$

One detail held significance for the emerging shape of rural political community. The executive order did not change the governance structure of the collective farms to empower the new shareholders in decision-making. The office of collective farm director ${ }^{299}$ persisted from Soviet times, ${ }^{300}$ often encumbered by the same person. ${ }^{301}$ To distribute land certificates, the central government depended on collective farm directors, who proved spottily unreliable in the task, ${ }^{302}$ perhaps reluctant to undermine the institution upon which their director status depended. ${ }^{303}$

ZemLyu [Legislation of UkRaine on LAND] 162-63 (Urinkom Inter 2002) [hereinafter Legislation of UkRAine on LAND]. The order retained $10 \%$ of each state farm's acreage to be held and administered by a public entity, the village council (silska rada, a local elected body).

297. Timchasoviy Poryadok Provedennya Robit Vydachy Derzhanykh Aktiv Kolektivnym Silskohospadarskim Pidpryemstvam, Siskohospodarskim Kooperativam, Silskohospodarskim Aktsionernim Tovarstvam, u tomu Chisli Stvorenym na Bazi Radhospiv ta Inshikh Derzhavnikh Silskohospodarskhikh Pidpriemstv, na Pravo Kolektivnoi Vlasnosti Na Zemlyu [A Temporary Order for Carrying Out Work of Given Government Acts to Collective Agricultural Enterprises, Agricultural Cooperatives, Agricultural Joint-Stock Companies, and those formed on the Basis of Sovkhoz and Other Governmental Agricultural Enterprises, on the Right of Collective Ownership to Land], confirmed by Order of the State Committee of Ukraine on Land Resources, No. 18/15, Mar. 1995, reprinted in Legislation OF UKRAINE ON LAND, supra note 296, at 162-63.

298. Id.

299. See Model Collective Farm Charter, 10 Spravochnik Partinogo Rabotnika ("Handbook of the Party Worker") 175 (1970), cited in Donald D. Barry, The Spravochnik Partinogo Rabotnika as a Source of Party Law in Ruling Communist Parties and Their Status Under Law 37, 45 (Dietrich A. Loeber ed., 1986).

300. C.P.W., Collective Farming in the U.S.S.R. Post-War Consolidation of Control. 11 WorLD TodAy, 470, 470-71 (1948), available at http://www.jstor.org/stable/40392073 (describing the post-War office of the collective farm director in the U.S.S.R.).

301. See generally Jessica Allina-Pisano, The Post-Soviet Potemkin Village: Politics and Property Rights in the Black Earth (2008).

302. Id. at 69-72 (describing how collective farm directors retained control of share certificates).

303. See Katherine Verdery, Seeing like a Mayor Or, How Local Officials Obstructed Romanian Land Restitution, 3 ETHNOGRAPHY 18 (2002) (suggesting that in neighboring 
The Constitution of independent Ukraine, passed in June $1996,{ }^{304}$ ensured that private ownership of land in Ukraine was not per se illegal, ${ }^{305}$ removing a handy cudgel from the Left's arsenalbut neither did the new Constitution require decollectivization. In this uncertain milieu, sources of directors' authority was shifting from formal position to new forms of social and cultural capital and their positional power, as a parliamentary voting block and in local economies, increasingly lost footing as regionally based klani emerged. ${ }^{306}$ This shifting position accelerated when the meaning attached to the land share certificates expanded. In 1999, an executive order decreed that a land share certificate refer to a demarcated plot of land, not merely an intangible share in the collective, implying that in principle a certificate-holder could elect to withdraw from collective production and farm independently. ${ }^{307}$

In the presidential election of 1999, land share distribution clearly correlated with voter preference. In areas where the certificates had been issued, incumbent President Leonid Kuchma was the clear winner; in areas where directors managed to withhold them, Communist Party candidate Petro Symonenko, who opposed privatization, won overwhelmingly. ${ }^{308}$ Presented with this evidence, the first presidential decree Kuchma signed after re-election in December 1999 disbanded the post-Soviet successor to the collective farms ("collective agricultural enterprises") entirely. ${ }^{309}$ At the same time, the state changed its system of assisting farm production, switching from directly supplying inputs to subsidizing interest rates for agricultural loans, ${ }^{310}$ giving producers more control over what to grow and how, but also increasing the role of lenders and the status of gatekeepers facilitating or controlling access to them.

Romania, local officials resisted distributing titles, a finite good which once given out could no longer serve as a basis for patronage).

304. See Konst. Ukr., supra note 291, art. 41.

305. See id. arts. 13-14.

306. See infra Section III.C.

307. See Presidential Order No. 720/95 on Parcelization, supra note 296.

308. See Andras Bozoki \& John T. Ishiyama, The Communist Successor Parties of Central and Eastern Europe 403-404, 408 (2002) (detailing the 1999 presidential election results).

309. Pro Nevidkladni Zakhodi shchodo Priskorennya Reformuvannya Agrarnoho Sektora Ekonomiki [On the Uninvested Means concerning Accelerating Reform of the Agrarian Sector of the Economy], Decree of the President of Ukraine No. 1529/99, Dec. 3, 1999, reprinted in LegisLation OF UKRAINE ON LAND, supra note 296, at 85.

310. See id. 
The next step in this experimental path towards privatization, constitution-implementing legislation explicitly authorizing private ownership of land, passed in October 2001.311 A tectonic shift in the constitution of political community was underway. The new Land Code conferred the right to a parcel of land, not just to a shareholder certificate. ${ }^{312}$ By June 1, 2002, just over six months after the new Code passed into law, $41 \%$ of eligible farmers had asserted their claim to a parcel. ${ }^{313}$ In parliamentary elections in March 2002 (six months after the Land Code passed), pro-reform parties won $70 \%$ of parliamentary seats allocated to party lists; Communist Party seats fell to $20 \%$, their lowest ever. ${ }^{314}$ Initially interpreted as a sign of widespread rural pro-privatization sentiment, subsequent reactions and lived experience proved more difficult to interpret.

This dramatic process of decollectivization took place against another, much quieter revolution in the relationship between citizen and locality. The most direct bureaucratic link between citizen and locality in Soviet life had been the residential registration (propiska) and internal passport system. ${ }^{315}$ It required every Soviet citizen to register residence with state authorities, binding each to a locale, and to carry an "internal passport" as identity document. ${ }^{316}$ These measures to regulate mobility on Ukrainian territory bore a distinctly colonial cast, originating in the late eighteenth century as a means to eliminate Ukrainians' free movement and extend Russian imperial control southward overly newly acquired Ukrainian territories. ${ }^{317}$ The Soviet government sus-

311. See Land Code, supra note 17.

312. See id.

313. See A Good Deed Indeed for Owners of Farmland, Kyiv WeekLy (Ukr.), June 14, 2002, at 21.

314. See Organization for Security and Cooperation in Europe (OSCE) Office of Democratic Institutions and Human Rights, Ukr. Parliamentary Elections 31 Mar. 2002 Final ReP. 24 (May 27, 2002), available at http://www.osce.org/odihr/elections/ ukraine/14947?download=true.

315. See generally Eppinger, Law and Land IV, supra note 289, at 117-22. See generally Mervyn Matthews, The Passport Society: Controlling Movement in Russia and in the U.S.S.R. (1993) (discussing the passport system and its accompanying bureaucratic processes). See also Tova Hojdestrand, The Soviet-Russian Production of Homelessness: Propiska, Housing, Privatization (2003), available at http://www.anthrobase.com/Txt/H/ Hoejdestrand_T_01.htm (discussing the role of propiska in Soviet and post-Soviet Russian society).

316. See Matthews, supra note 315.

317. See Z. Kohut, The Abolition of Ukrainian Autonomy, 1763-1786: A Case Study in the Integration of A NON-Russian Area into the Empire, 208-306 (1975) (Ph.D. thesis, University of Pennsylvania); see also Isabel de Madariaga, Russia in the Time of CatheRINE THE GREAT 68, 308-14 (1981). 
pended them briefly after the 1917 Revolution, only to re-impose mobility restrictions during the Famine in 1933, a lethal way of keeping peasants on the collectives and out of bread supplies meant for urban workers. ${ }^{318}$ During the late Soviet period, more positive incentives reinforced bonds of affiliation between a citizen and her locale, for example a constitutional guarantee of housing in the 1977 Soviet Constitution. ${ }^{319}$

Soviet mobility restrictions were abolished by deliberate omission from the 1996 Constitution of independent Ukraine. ${ }^{320}$ The state, for the first time since 1783 , does not seek to control mobility of its citizens. The new Constitution affirmed the right to change residence and workplace without permission or control from state authorities. ${ }^{321}$ (Although it does allow for a system of local registration, registration does not bind the citizen to a particular locale;322 it is purely an administrative measure for organizing rights like suffrage or obligations like tax payment, not for blocking mobility.) Under the 1996 Constitution, any Ukrainian citizen has the right freely to leave the territory of Ukraine, meaning an international passport is available to any Ukrainian citizen who applies for one. ${ }^{323}$

Five million, or $10 \%$ of the population, availed themselves of an international passport and ended up residing outside Ukraine-at least temporarily-since independence. ${ }^{324}$ Others who stayed in Ukraine largely stayed put, until an abrupt change after October 2001. In other words, the period of actual land privatization, during which collectives were divided up and farmlands parceled as property to resident farmers, coincided with a mass exodus of the

318. Resolution of the U.S.S.R. Central Executive Committee and Sovnarkom, "Ob ustanovlenii edinoi pasportnoi sistemy v SSSR" [On the Establishment of a Unitary Passport System of the U.S.S.R.] (December 27, 1932), promulgated in Pravda 1 (December 28, 1932). See Moshe Lewin, The Making of the Soviet System: Essays on in the Social History of Interwar Russia 220 (1985); see also Stephen Kotkin, Magnetic Mountain: Stalinism as Civilization (1995) (describing the role of bureaucratic measures like the propiska and policy decisions in construction of a way of life particular to the Soviet Union under Stalin).

319. See Konst. SSSR, supra note 116, art. 44.

320. See Konst. Ukr., supra note 291, art. 33 (omitting mobility restrictions, guaranteeing freedom of movement).

321. Id.

322. Pro Svobodu peresyvannya ta viln'nyy vybir mistsya prozhivannya v Ukrayini [The Law of Ukraine "On Freedom of Movement and Free Choice of Place of Residence in Ukraine"] art. 3.

323. See Konst. Ukr., supra note 291, art. 33.

324. Roughly two million emigrated permanently. The other three million left as labor migrants, intending to return to Ukraine. See Labor Migration Hearing, supra note 211. 
newly-endowed farmers from the countryside. After the passage of the Land Code, at least $20 \%$ of the Ukrainian population, roughly 10 million people, evacuated their homes and moved to a new location within Ukraine; the majority are rural out-migrants. ${ }^{325}$ The remainder of this Section explores the "ghost towns" abandoned by the majority of their newly enpropertied residents.

\section{B. Life in the Ghost Town}

The scene at the Red Star farm was impressive in its uniformity with most other Ukrainian villages five years after the Land Code passed. The countryside was empty except for a couple of late middle-aged women diligently hoeing rows of beets by hand, exhausted. ${ }^{326}$ The weather. The isolation. But mostly, the work. It was back-breaking and they were too old for it. At some point in our conversation, a man their age wandered up and pointed out that what you would find here, as in most villages: newly-privatized land plots; old Soviet combine harvesters, long since cannibalized for parts; middle-aged and elderly farmers -- but no youth. Everyone who could leave, had left. ${ }^{327}$ Pani Halya and Pani Irena introduced me to the newcomer as "nash traktorist," "our tractor-driver," although they had not had a working tractor for more than five years, nor a joint farming operation for more than eight years. ${ }^{328}$ The significance here is that the collective farm had disappeared but collective identity remained. By 2007, this scene was by far much more the norm than the boomtown. ${ }^{329}$

I would go back in a minute.

Serhiy, a young agricultural specialist, was excellently situated when the land privatization measures were handed down. His father had a seat on the local committee in charge of parcel allotments on their collective farm and so could secure choice holdings for them; Serhiy had earned a degree in farm management from an agricultural college; and he expressed a personal preference for

325. See IOM Labour Migration Assessment, supra note 210.

326. See Eppinger, Law and Land IV, supra note 289, at 77.

327. See Interview with Halya Prikhoda, Irena Kirova, and Petro Kiyashko, Farmers, Former Red Star Collective Farm, in Kirovograd oblast', Ukr. (May 31, 2007), cited in Eppinger, Law and Land IV, supra note 289, at 77.

328. Id.

329. For example, in Chernihivska oblast', of 1489 settlements in the region, 114 now have 10 inhabitants or less and 23 have no inhabitants at all. See Oksana Sukhova, Is it Real to Have Effective Land Administration When There is Power Dispropriation, paper presented to International Federation of Surveyors FIG Congress (Apr. 11-16, 2010), available at https:/ /www.fig.net/pub/fig2010/papers/ts09j\%5Cts09j_sukhova_3856.pdf (describing wholesale rural flight). 
living on the farm. Yet I found him in a back office in the city center of Kherson, selling seeds and fertilizer to farmers as regional manager for a Jordanian agricultural inputs supplier. It was hard to find someone of Serhiy's generation in most villages. Why had people abandoned their farmlands so soon after receiving private property rights in them? Why had he?

No one organizes anything any more. We used to have cinema, right there on our collective farm, every weekend the latest films; dances in the summer; soccer games between our boys and the neighboring farm. Now it's all fallen apart. The work; the play. Nothing is organized. You go there and you're on your own. And it's too much to organize everything yourself, without counterparts on other farms or help from the center. There's no one to send us films, much less seeds or tractors. Kids like me would be happy to go back to the village if someone were organizing things. ${ }^{330}$

The disintegration of rural social life, particularly but not only labor, became a repeated theme in my interviews with rural outmigrants. Those left in the villages, however, attest to the egalitarian experience of politics. ${ }^{331}$ A portrait of this new political and economic order emerges from one typical village, Plotno, in northeast Ukraine near the border with Russia and Belarus'. ${ }^{332}$ The productive lands of Plotno consist of fields formerly farmed for wheat and pastures supporting a herd of some 200 cattle. ${ }^{333}$ The former collective farm fields are surrounded by a state forest rich in the pine and beech from which each household carefully builds up a substantial woodpile before the first snows. Villagers avidly gather wild foods, primarily mushrooms carefully dried for winter soups, but also berries, honey, small game, and fish from the state forest. $^{334}$ Plotno prides itself on having been wired with electrical power during the Soviet "rural electrification" campaigns of the late 1920s, but like many villages in Ukraine, Plotno has never been connected to a natural gas trunkline and each household depends on a wood-fired stove for heat during the cold seasons. ${ }^{335}$

330. Interview with Serhiy Haydyuk, Regional Manager, Agrimatko Agricultural Inputs Supplier (Kherson city, Kherson oblast', Ukr., (June 5, 2007), cited in Eppinger, Law and Land III, supra note 214, at 5-6.

331. See Eppinger, Law and Land IV, supra note 289, at 91.

332. Observations of the productive activities in Plotno village and interviews were conducted by the author in September 2009, with follow-up interviews over the subsequent 18 months.

333. See Eppinger, Law and Land IV, supra note 289, at 91.

334. Id. at 94-95.

335. See Eppinger, Law and Land III, supra note 214, at 105. 
Plotno itself is a settlement of wooden houses dating from before the 1930s, each skirted by a plank-fenced yard in front and a substantial kitchen vegetable garden in back; a few local administrative buildings, school, clinic, and general store; and the deserted and decaying former collective farm cattle shed. ${ }^{336}$ The lands of the collective farm that encompassed Plotno were divided and allocated only after the new Land Code passed in 2001. Each household received a long, narrow strip of about two acres. ${ }^{337}$ Most of that land has gone to seed. Fewer than a tenth of it is farmed by its current owners, and none grow grain. Cultivation serves subsistence needs. Those that cultivate beyond their kitchen gardens grow potatoes, carrots, or beet-roots for human or livestock winter provision or hay for livestock in the winter. ${ }^{338}$ The rest of the former collective farmland now under private ownership lies uncultivated, occasionally foraged by the villagers' cattle. The few households that have cultivated their collective-farm parcel-and managed to turn a profit-also keep a pig. ${ }^{339}$

The only vestige of collective farm cultivation that still produces food or livelihood is the collective-farm apple orchard. Understood as a unique resource, the 10 acres of apple trees outside the village have not been apportioned to any one owner during privatization. ${ }^{340}$ Rather, each household helps itself to as many apples as it cares to gather in season. Villagers complain that the orchard is declining in production because of the lack of systematic care for the trees. ${ }^{341}$ It still supplies more than all of the households who bother can gather, and apples fall rotting into the early autumn grass.

The current mayor had formerly been the village high school teacher before becoming the town mayor, he admitted with a shy smile when prompted by a neighbor. ${ }^{342}$ That older neighbor proudly confided she is the village king-maker, taking credit for picking the village teacher to stand for election. It had not been easy to convince him. "The new one, he's letting me down too, but

\footnotetext{
336. See Eppinger, Law and Land IV, supra note 289, at 89.

337. Id.

338. Id. at 89-90.

339. Id.

340. Id.

341. Id.

342. Id. at 93 .
} 
no one else will do it." ${ }_{433}$ In fact, in this village of now 400 residents, a disproportionate percentage over 45 , with more than two decades of post-Soviet political power and nearly thirteen years since decollectivization, constraints on concentration of power and structures favoring egalitarianism were so strong - there was so little wiggle room for public advance or private gain - that it was getting hard to scare up volunteers to run for local office every election. ${ }^{344}$

Others in the village confirmed this post-Soviet experience with elected government. "So, you were the head of the village council?" I asked Serhiy. Serhiy, one of the few car owners in this hardscrabble village, had been drafted into driving me to the train station five miles away because he regularly receives milk from my hosts' cows. "Yep, 2002-2006. First and last time," he smiled ironically, his gold molar replacements gleaming, bemoaning the "thankless job": "all our resources go to Kyiv and no help comes back. Somehow you have to do something with this impossible situation, you want to and everyone expects you to." 345 This was a strange result of multiparty democracy and the dissolution of a unified village economic organization. Elections in their village were free, everyone agreed, but no one really wanted to hold office.

\section{Review of the Ghost Town}

In this Section, I reviewed the legal and policy measures introduced to divide up collective agricultural holdings and to lift state restrictions on mobility over the first ten years of Ukrainian independence. Legal measures to institute private property rights in land were shaped by conceptual categories, allegiances, and habits from the collectives and embroiled in political struggles over executive versus legislative power, or between klani whose clients encumbered those branches. I also described some of the ways those changes affected local practice and experience. How do these results stack up against claims and predictions made in privatization models? For property owners in the ghost towns, private property did not create wealth. It was, instead, a nail in the coffin of a system of agricultural production, social safety net, identity,

343. Interview with Tyotya Ksyusha, Farmer and Former Head of Dairy Production for the Collective Farm, Plotno Village, Sumi oblast', Ukr. (Sept. 20, 2009), cited in Eppinger, Law and Land IV, supra note 289, at 89-90.

344. See Eppinger, Law and Land IV, supra note 289, at 89.

345. Interview with Serhiy Khlib, Farmer and Former Town Mayor, Plotno Village, Sumi oblast', Ukr. (Sept. 21, 2009), cited in Eppinger, Law and Land IV, supra note 289, at 90 . 
and social organization. While the ghost town was disastrously less successful than predicted in reaping the productivity gains expected from decollectivization, it was remarkably more democratic, with local property owners enjoying greater political power than in the past vis-à-vis collective farm leadership and local Party leaders. The ghost town is populated by the lonely autark, impoverished, calling self and fellow villagers by identities held in the long-gone collective farm rather than by "farmer" (Ukrainian and Russian fermer), a term I only heard used by policy types and investors in the cities. Many preferred rural life, if it was organized into a modern system of mechanized farming and community action. As individual private property owners, they found themselves in conditions of autarky that struck them as premodern. The city, or the corporations within it, offered the closest approximation to a modern life, life in a collective mode, within their known set of alternatives. One self-designation for this younger generation of literate strivers-not those who found blue-collar work, but those who managed to find white-collar jobs in the new corporations of Ukrainian cities-is offisniy plankton, "office plankton," surviving adrift at the bottom of the food chain. ${ }^{346}$ Those in the exceptional case, the fortunate farmers of the boomtown, found in their oligarchic patron someone willing and able to reconstitute a form of modern, collective production. They were not insensitive to some of its power imbalances; what they enjoyed were benefits they associated with a resurrection of the kollektiv: training, new equipment, belonging, wage labor, reduced exposure to weather and other farming risks. In both cases, the former collective farmers conceived of themselves as workers in a modern enterprise.

British sociologist Guy Standing, analyzing a global wave of economic reforms that transfer risk and insecurity onto workers and their families, has identified a group that loses; for them, he has coined a demographic term that seems etymologically particularly apropos in the former Soviet space: the Precariat. ${ }^{347}$ The figure we see emerging from the ghost town, then, is the Precariat, those who materially suffered a net loss from liberal reforms and those who have thus far successfully scrambled through but who experi-

346. See, e.g., Kateryna Grushenko, In Recession, Employers Look for High-Fliers, not "Office Plankton”, Kyrv Post (Oct. 29, 2009), http://www.kyivpost.com/content/business/in-reces sion-employers-look-for-high-fliers-not-of-51507.html.

347. See Guy Standing, The Precariat: The New Dangerous Class 1 (2011) [hereinafter Standing, Precariat]. 
ence vulnerability and fear becoming a loser for reasons beyond their control.

\section{Conclusions: Property in the Present, Democracy in the Subjunctive}

\section{A. Three Accounts of Property, Reconsidered}

In Western legal scholarship, several traditional accounts of the relationship between property and political community give rise to the conviction that private property, prosperity, and democratic self-governance are mutually reinforcing. My aims in this Article are not to refute any one of those traditional accounts but are rather more modest: to disaggregate, compare, and reframe. The first aim is to disaggregate claims from separate accounts that ideology had lumped together. Considering them as separate accounts reveals liberty, wealth, and democracy as organizing principles of political community all thought to ensue from private property ownership. Often cast as part of the same package, we see they arise from different accounts that have not always understood themselves as mutually complimentary. A second aim is to compare predicted results of land privatization with lived experience of it. The results we observe in post-privatization Ukraine vary from Western predictions. These findings stand as a warning against what anthropologist Carolyn Rouse calls "development hubris" 348 and as a challenge to the projection of Western social formations and epistemologies onto others. Another aim is to reintroduce the notion of contingency in analyzing social effects of property. Our reply to the pre-existing accounts' rhetorical question, Doesn't private property create prosperity and democracy, is rather, "not necessarily," at least in two respects.

First, the effects of creating private property can vary, even within one polity. In Ukraine, we see clearly bifurcated results. In the boomtowns, we see remarkable productivity gains accompanied by significant disempowerment of the new landowners. In the ghost towns, we see fairly robust democracy, at least among those left, but impoverishment. The same reform processes might create inflow of investment and outflow of population, wealth or empowerment, boomtown or ghost town. Private property is, itself, not sufficient to predict outcomes.

348. Carolyn Rouse, Development Hubris: Adventures in Trying to Save the World (unpublished manuscript under review, 2014). 
Second, reform processes might create exactly the expected result, but not only that result. Private property might create wealth as predicted but the original account may not have addressed distribution of wealth. It could be that an associated effect-such as distribution-proves more significant in the constitution of political community. In the empirical case at hand, in addition to concern with the wealth of the nation, a Jeffersonian concern with distributions of property and wealth at the founding of a new polity might also be germane to the quality of the emerging political community. ${ }^{349}$ Our endorsement of Jefferson's agrarianism is limited. Jefferson's own repugnant slave-holding practices lead us to reject his claims about a necessary relationship between property, farming, and civic virtue. Further, romanticizing the selfsufficiency afforded by subsistence agriculture, a hard sell in Jefferson's time, is even more difficult to sustain in our own when subsistence agriculture would suffer in competition with industrial agriculture and its economies of scale. Rejecting Jefferson's politics of property virtue and the presumed empowering material base of subsistence agriculture does not defeat the overall concern on which we rest, that unequal control over property may have deleterious effects on construction of a political community that aims to be a democracy.

\section{B. Two New Figures and One Turn of Events: The Oligarch, the Precariat, and Revolution}

Several central figures still dominate the imagination of Property scholarship today: the Rugged Individual, the Free-Wheeling Trader, the Self-Sufficient Democrat. Looking to the former socialist space, prior property accounts prepared scholars to see individuals heretofore unluckily trapped in tragic collectives poised to become one of these figures if enabled by privatized property. What these accounts did not equip scholars to recognize was the Kollektiv; what they were not equipped to predict was what might emerge from the Kollektiv. The Ukrainian case brings to light two other possible figures. One is the "winner" from property reforms, the Oligarch, by which we mean both the person heading a political-economic social formation and the aspirants-managers, rivals, dreamers-that would be head. Possible connections between the

349. Sunstein was thus wrong to focus on small-holder empowerment through subsistence agriculture, at least absent much broader change in world agricultural production. The larger question of distribution, rather than autarky, should have been the focus of Sunstein's argument. 
arising of the Oligarch and the Kollektiv ${ }^{350}$, entrepreneurial governmentality, ${ }^{351}$ or other structures of late socialism await further study. I propose that, democracy rhetoric aside, the creation of private property is a necessary precondition for the arising of the Oligarch in the former socialist space. A second figure is the loser of liberal reforms, the Precariat, by which we mean the person who did not gain, socially or economically, from these reforms even if they made her a property owner de jure. This group also includes the class of people who have not lost yet: who fear, reasonably, becoming a loser of the reforming economy. ${ }^{352}$

In the case examined herein, several unexpected turns of events associated with these figures followed land privatization in Ukraine. One was the massive "flight from property." Rural residents who had already stayed on the farm through ten years of post-Soviet economic depression took flight in mass exodus from the countryside only after decollectivization and their endowment with private property ownership. ${ }^{353}$ Some explanation for flight comes from villagers themselves. They were modern workers used to factory farming in an organization characterized by division of labor, specialization, steady income, and certain forms of companionship and sociability. Decollectivization meant the loss of that and a shift to autarkic production. It was modernity and its forms of collective production that evoked pride and stability in the boomtown and inspired flight to cities, the next closest social formation to the one they had lost, from the ghost town.

A second unexpected turn was the arising of a "super-renter" 354 class of oligarchs. Food processing and transport enterprises funnel the produce of the countryside through limited hands to market. Know-how and connections funnel the collateral value of smallholders' parcels to financial markets. Smallholders depend on gatekeepers and middlemen for interaction with sources of international financial capital and representation in the political capital. The revolution of 2014 in Ukraine saw mass precariat protests against an increasingly authoritarian klan and against oligar-

350. See infra Section II.A.3 (proposing the Kollektiv as the central figure arising from Soviet collective land ownership).

351. See Yurchak, Entrepreneurial Governmentality, supra note 261.

352. For a sociological description of the precariat, see generally Standing, Precariat, supra note 347.

353. See infra Section IV (describing lands and villages abandoned after privatization).

354. Verdery, Vanishing Hectare, supra note 223, at 310-38. 
chy in general. ${ }^{355}$ In 2011, Standing had raised the question of when the Precariat would turn "from theater and visual ideas of emancipation" a lá the Occupy protests to effective action, which to his imagination at the time meant "a set of demands that will engage the state." ${ }^{56}$ In 2014, Ukrainians skipped from engaging the state to overthrowing the government in attempt to permanently dislodge oligarchy. Their success in that endeavor has yet to be determined.

My claims about the relationship between land privatization and the Ukrainian crises of 2014 are also modest. I do not claim that following Western property advice directly caused the revolutions, counter-revolutions, and state vulnerability of 2014. I do suggest that those who offered advice, opinion, and scholarship-with the best of goodwill and intentions-in the early 1990s revisit the scene now that that advice has been implemented. I further propose that the 2014 revolutions cannot be understood without taking into account relationships between property, oligarchy, and precarity. Mindful that the story is not over, an equilibrium state has not been reached, history is still unfolding-the Precariat may yet become the self-sufficient citizenry or re-dominated by oligarchywe also suggest that in other contexts, the relationship between property and state vulnerability is due for re-examination.

\section{Property and Political Community}

We view the scenario in Ukraine, then, with one eye on ourselves. Reviewing the legislative history of land privatization in Ukraine reminds us of a recursive relationship between law and authority. Legal positivism takes authority for granted: law is a genre of speech act issued by a particular set of authorities. The post-Soviet context, under conditions of rupture, shows instead a dialogic relationship between the speech act, a social and political structure still in formation, and the unsettled position of the party issuing it. ${ }^{357}$ That party is jockeying for power, playing for resources, and trying to establish authority.

By 2004, in national politics Ukraine enjoyed a lively democracy in the sense of hotly contested elections whose outcome was not

355. See, e.g., Andrew Higgins \& Andrew E. Kramer, Archrival is Freed as Ukraine Leader Flees, N.Y. Times, Feb. 23, 2014, at A1 (describing the overthrow of one oligarchic klan in the 2014 revolution).

356. Standing, Precariat, supra note 347 , at 3.

357. See Monica Eppinger, Sages, Savages, and Other Speech Act Communities: Culture in Comparative Law, 57 ST. Louss U. L. J. 407 (2013) (proposing performativity can serve as a basis for analyzing components of culture). 
predetermined. Examining our use of the term "democracy" more closely, however, we see a difference between democratically selected leaders and functioning citizen self-governance. National elections increasingly reflected contests between rival oligarchs to select which klan would populate state institutions. National politics seemed to have become the province of an elite using it as a field on which to compete amongst themselves. Citizens increasingly seemed spectators to politics.

Enter the Precariat. The protests of 2013 brought millions to activism. The oligarchic presidency they deposed in February 2014 exposes the extent to which political and economic elites had come to overlap: an economic elite pays for elections from the profits of the privatized sectors and a political elite uses government positions to leverage information asymmetries or otherwise secure profitable assets. This scenario recalls concerns about "regulatory takings" as a threat to property and thus liberty until one realizes that the private sector is no refuge. It is even unclear that, for elites, a private sector distinct in actors or schemes of action from a state sphere exists. Social facts highlight the possibility of an identity relationship between political and economic elites. The current citizen challenge to them reopens a political ontology oriented towards an open future, towards the way that things could be.

The picture revealed by this investigation raises concerns in other contexts about relationships between property and democracy, or more precisely, between the propertied and broad citizen self-governance. The data here remind us that property and democracy are both emergent institutions, not static, in any context. Emergent, contingent, and not always mutually felicitous. 
